University of Louisville

ThinkIR: The University of Louisville's Institutional Repository

Electronic Theses and Dissertations

1930

\title{
Types of children in Dickens' novels.
}

J. T. Highfield Mrs.

University of Louisville

Follow this and additional works at: https://ir.library.louisville.edu/etd

Part of the Literature in English, British Isles Commons

\section{Recommended Citation}

Highfield, J. T. Mrs., "Types of children in Dickens' novels." (1930). Electronic Theses and Dissertations. Paper 1793.

https://doi.org/10.18297/etd/1793

This Master's Thesis is brought to you for free and open access by ThinkIR: The University of Louisville's Institutional Repository. It has been accepted for inclusion in Electronic Theses and Dissertations by an authorized administrator of ThinkIR: The University of Louisville's Institutional Repository. This title appears here courtesy of the author, who has retained all other copyrights. For more information, please contact thinkir@louisville.edu. 


\section{UNIVERSITY OF IOUISVIIIE}

\section{TYPSS OF CHIIDRJIT IN DICKENS' NOVELS}

\section{A Dissertation}

Submitted to the Faculty Of the Graduate School of the University of Louisville In Partial Fulfilment of the Requirements for the Degree

Of Naster of Arts

Department of English

By

Mrs. J. T. HighfieId 
Introduction $\ldots \ldots \ldots \ldots \ldots \ldots \ldots \ldots \ldots \ldots \ldots \ldots$ Page 1. Chapter 1, Oliver Twist, the Workus Orphan,........ Page 4 . Chapter 11, Poor Smike, the Nameless Drudge,........ Page 21 . Chapter 111, Little Dorrit, the Child of the Narshalsea Page $3 \%$. Chapter IV, Pip, the Convict's Beneficiary,.......... Page 52 .

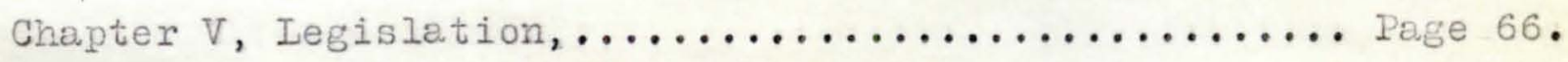
Conclusion $\ldots \ldots \ldots \ldots \ldots \ldots \ldots \ldots \ldots \ldots \ldots \ldots$ Page 82 . Bibliography $\ldots \ldots \ldots \ldots \ldots \ldots \ldots \ldots \ldots \ldots \ldots \ldots \ldots \ldots$ Page 85. 
INTRODUCTION 


\section{Introduction.}

Of all the novelists of all times, Charles Dickens has given us the best pictures of underprivileged childhood. His lave and sympathy for children have made him their champion and advocate in a time when they were regarded as necessary burdens till they reached maturity and could depend upon themselves for support. In his restless evening walks to all parts of the great pulsating city of London, in his travels to many places in England itself, he was impressed with the hopeless conditions surrounding childhood everywhere. There were children ground down by the exploitation of employers engaged in many trades. Others were cowed into submission by heartless and ignorant schoolmasters whose very names had become notorious with deeds of cruelty and neglect. others felt the donination of their elders to such a degree that all personality and life were crushed out, as one tramples out the life of a beautiful flower. Still others there were who found themselves shouldering responsibilities too heavy for their immature years. Nor could Dickens resist the pleading of these little children, lost in the maze of extortion, poverty, and untold misery. Into his memory came crowding recollections of his own bitter childhood as he pasted labels on blacking bottles, stained, as it were, with his very life's blood. Other days were stanped indelibly on his unforgetting soul, memories of the foul larshalsea prison, memories of a certain establishment of learning conducted by an unlearned, unscrupulous master of doubtful 
origin, memories of his miserable little companions, sunk to levels of unspeakable deterioration, memories of hunger and cold, of misunderstanding and poverty of the most abject kind. Never could Dickens forget these heartrending years of his childhood, even after he had been proclaimed an author of the first rank. Wot even to his close friend and biographer, John Forster, did he reveal the experiences of those hidden years until long after his success was established and he had conceived the idea of writing his autobiography.

As if his childhood experiences had been too hard almost to bear, as if he could not endure the sight of other children undergoing sufferings too bitter for their tender years, Dickens undertook voluntarily the task of making childhood easier by attempting to alleviate circumstances disposed to keep it difficult. Mor was he alone in his undertaking, for Lord Shaftsbury was already engaged in his project known as the Ragged Schools. Madame Ronge' had opened the first kindergarden in Iondon, and her assistant tells us that Dickens was a frequent visitor. It was Dickens, however, who was able to do most towards arousing public sentiment that was destined to bring about some reforms. Hughes, in his Dickens as an Educator, says, "Dickens is beyond comparison the chief English apostle of children, and its leading champion in securing a just, intelligent, and considerate recognition of its rights by adulthood." In a discussion of The Chines, Forster tells 
us, "The poor had always been his clients, they had never been forgotten in any of his books, but here nothing else was to be remembered..... When he came, therefore, to think of this new story for Christmas time, he resolved to make it a plea for the poor. He was to try and convert society, as he had converted Scrooge, by showing that its happiness rested on the same foundation as those of the individual, which are mercy and charity not less than justice."

However, we must not leave the reader with the impression that all the children of Dickens' novels were oppressed and cast down by sorrow. In fact, we find some delightful boys and girls who had no cause for complaint. Yet it was the general rule in the first half of the nineteenth century that the children of the poor received no consideration whatsoever. Consequently, Dickens' championing of their cause proved to be a great boon to them. It is with this fact in mind that we have chosen to discuss some of the outstanding child characters of Dickens' novels. It is our desire to show how the author agitated for reforms thru them as he exposed the conditions and circumstances of their lives. It is by their trials that the public was aroused to action resulting in a better chance for normal childhood. In the following chapters, we shall consider Oliver Twist, poor Smike, Little Dorrit, and Pip; and we shall endeavor to portray how Dickens struck at some wrongs thru the medium of these characters.

3. Iife of Dickens, John Forster, Abridged and Revised by Geo. 
CHAITER I

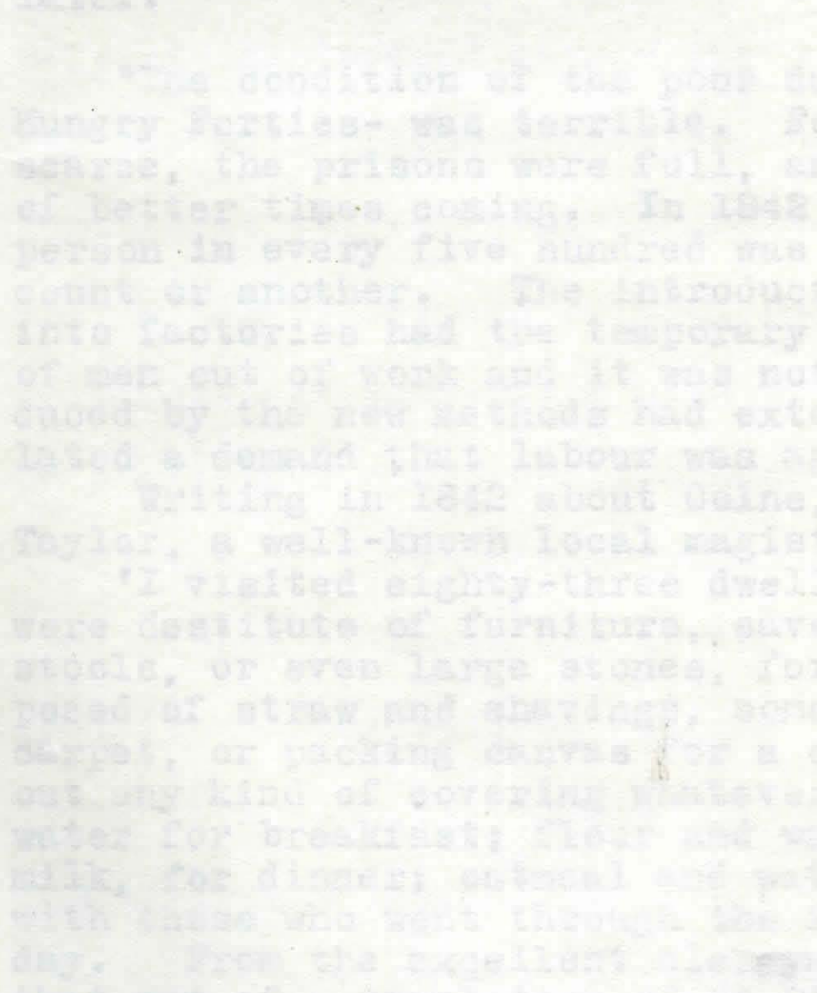




\section{Chapter I.}

\section{OIIVER TWIST; THE WORITUS ORPHAN.}

With oliver. Twist Dickens began his children's

crusade, which he continued at intervals during the rest of his career as an author, and, to be sure, almost till his death. oliver Twist was written during one of the saddest times in the history of Ingland. The country was in a state of evolution from manufacturing at home to manufacturing in the factory. Coal, iron, and steam, the magic trinity of progress, were beginning to come into their own, leaving unemployment and with it poverty and starvation in their wake. Hayward in his The Days of Dickens says of the time a little later:

"The condition of the poor during the early ' 40 's- the Hungry Forties- was terrible. Food was dear, work was scarce, the prisons were full, and there seemed no prospect of better times coming. In 1842 it was reckoned that one person in every five hundred was committed for trial on some count or another. The introduction of steam and machinery into Iactories had the temporary effect of throwing thousands of men out of work and it was not until the cheap goods produced by the new methods had extended our markets and stimulated a demand that lebour was again required extensively. Writing in 1842 about Colne, Lancashire, Dr. W. Cooke Taylor, a well-known local magistrate observed:

'I visited eighty-three dwellings selected at hazard; they were destitute of furniture, save old boxes for tables, and stools, or even large stones, for chairs; the beds were composed of strew and shavings, sometimes with torn pieces of carpet, or packing canvas for a covering, and sometimes without any kind of covering whatever. The food was Oatmeal and water for breakfast; flour and water, with a little skimmed milk, for dinner; oatmeal and water again, for a third supply, with those who went through the form of eating three meals a day. From the excellent clergyman of the town I learned, that out of a population of 53,000, no less than 13,000 were receiving parish relief; that the poor rates had risen from 3s. to 10s. in the pound; that the relief granted was deemed by the paupers so inadequate to their wants, that the relieving officer in one district was obliged to be protected by a military guard; and that the general ruin was fast absorbing the shop-keepers of Colne and the deiry farmers in the neigh- 
borhood. I went into several of the shops; the same tale was told by all; they saw nothing before them but bankruptey and ruin. ${ }^{1 "} 4$

John Forster gives us an additional touch in his

Iife of Charles Dickens when he says:

"Nevertheless, with the new Poor Iaw comes such a demand for new workhouses that in some four-and-twenty years we find an expenditure of Pive millions sterling in this hopeful direction. To be sure, a habit of pauperdom was threatening the min of the country- or of such parts of it as could not be saved by coal and steam and iron." 5 .

Such was the setting of oliver Iwist, and, in fact, such was the time in which Dickens lived; for it is significant that the scenes of most of his novels are laid in the nineteenth century, or, from his point of view, the present. Only his historical novels prove to be exceptions. Indeed, had the author done otherwise, he would have defeated his purpose at the very outset and would not have been able to aid in the subsequent reform, partly, at least, effected by his writings. In connection with the discussion of his other works, we shall have occasion to allude to and elaborate upon the brief treatment of the times which forms the introduction to this chapter. Thus we shall add to the at present incomplete picture so that the reader will be enabled to view it as a whole, and, in connection with it, to see what part Dickens was to play in the social reform of his day.

John Forster attributes to Dickens the first English novel of purpose in Oliver Twist. It remains for Ralph strauss to define that purpose for us when he says:

4. The Days of Dickens, A. I. Hayward, pp. 266 and 267.

5. Iife of Charles Dickens, John Forster, p.4.

6. Ibid, p. 62 . 
Mlany writers before him had attacked a civilized community which could permit such disgraces as the ill-treatment of children and the workhouse. Dickens attacked by ridicule, and succeded where his predecessors had failed." ?

To a public oblivious to the existence of that vast multitude of people known as "the poor", Dickens revealed, thru the medium of a child, the unspeakable existence of children in the workhouse, at the poor farm, and during apprenticeship. It was only thru the medium of a child, we say, that he could make his starting revelations; for no one can resist the appeal of innocence. Dickens draws for us a hideous background of greed and filth and crime and places in the foreground the goldenhaired purity of a little child, so that the gold is made to shine the brighter and the eviI to seem the blacker because of the contrast. What if the child seems a bit too good, too ideal to be of earth? The somberness of his surroundings stands out the clearer and is made the more horrible for his very innocence.

To Dickens, Oliver was a very real person, his own child, created out of the fancy of his fertile imagination, with whose life he was intimately associated. In a letter to one of his friends he said, regarding the reality of oliver:

"Can I do better than by saying that the sense of poor Oliver's reality, which I know you have had from the first, has been the highest of all praise to me? None that has been lavished upon me have I felt half so much as that appreciation of my intent and meaning,...." 8

7. Charles Dickens, A Biography from New Sources, Ralph Strauss, p. 138.

8. Iy Father as I recall Him, Mary Dickens, p. 59 . 


\section{7.}

To Dickens, all of his characters were actual people with whom he Iived dynamically during the writing of his books, and to whom he dreaded to bid farewell in the closing chapters. It was as if something very precious had gone out of his life, but another set of characters soon came in to fill the vacancy and give him new impetus to continue his task. So it was with each succeeding character, and so it was with Oliver Twist. Dickens gives us a very vivid picture of the birth of the child when he calls "the item of mortality whose name is prefixed to the end of this chapter." We see the groggy old woman as she gulps down quantities of gin from a large green glass bottle, between ministrations, such as they were, to the young mother. Then there is the surgeon who says, as he goes out, "You needn't mind sending up to me, if the child cries, nurse,.........It's very likely it will be troublesome. Give it a little gruel if it is." After oliver is dressed, Dickens adds a significant note. "But now that he was enveloped in the same old calico robes which had grow yellow in the same service, he was badged and ticketed, and fell into his place at once- a parish child-the orphan of a workhouse- the humble, half-starved drudge- to be cuffed and buffeted through the worlddespised by all, and pitied by none.

oliver cried lustily. If he could have known that he was an orphan, Ieft to the tender mercies of churchwardens and overseers, perhaps he would have cried the louder." 9

9. Oliver Twist, Charles Dickens, New York, 1902, pp. 3 and 4. This text will be used throughout this chapter. 
Our attention is drawn to the surgeon who is, to all appearances unmoved by the death of the young mother. His only recognition of her decease is that she is unmarried. He is oblivious to the fact that she has left a baby behind her. As for the drunken old mid-wife, her one reaction to the whole affair is that she bas another charge to care for. However, her troubles on that score are soon effectually drowned in the contents of the glass bottle. Such a happy event, Dickens intimates, is the birth of a parish chila!

Before the child had reached his first birthday, the board of the parish decided that he must be transported to the poor farm for children too young to be apprenticed to a trade at the workhouse, a sort of branch workhouse, "where twenty or thirty other young juvenile offenders against the poor-laws, rolled about the filoor all day, without the inconvenience of too much food or too much clothing, under the parental superintendence of an elderly female, who received the culprits at and for the consideration of sevenpence-halfpenny per small head per week. Sevenpence-halppenny's worth per week is a good round diet for a child; a great deal may be got for sevenpence-halfpenny; quite enough to overload its stomach, and make it uncomfortable. The elderly female was a woman of wisdom and experience; she knew what was good for herself. So, she apropriated the greater part of the weekly stipend to her own use, and consigned the rising parachial generation to even shorter allowance then was originally provided for them.

"Occasionally, when there was some more than unusually interesting inquest upon a parish child who had been overlooked 
in turning up a bedstead, or inadvertently scalded to death when there happened to be a washing; though the latter accident was very scarce- anything approaching to a washing being of rare occurrence in the farm- the jury would take it into their heads to ask troublesome questions, or the parishioners would rebeliously affix their signatures to a remonstrance. But these impertinences were speedily checked by the evidence of the surgeon, and the testimony of the beadle; the fomer of whorn had always opened the body and found nothing inside (which was very probable indeed), and the latter of whom invariably swore whatever the parish wanted; which was very selfdevotional. Besides, the board made periodical pilgrinages to the farm, and always sent the beadle the day before, to say they were going. The children were neat and clean to behold, when they went; and what more would the people have!"

Here then we see the poor farm of Dickens' day, a most degrading institution, its only redeeming feature being that the children were got rid of during a very troublesome period of their lives. Conditions were unpardonable. Regarded by the matron, Mrs. Mann, as so many nuisances, they existed or died without so much as a regret on her part. A child scalded or smothered to death was only an incident in a day's work. The children were allowed to go dirty and unkempt, with a hurried washing on the day the board came to inspect the farm and with an occasional clean outer garment to give them the appearance of always being tidy and comfortable. As for food, they never has enough, regardless of quality. A balanced diet was not 
known, but a sufficient quantity of any food, good or poor, was never to be had. They were always hungry, always undernourished, pale, anemic little morsels of humanity, uncared for and unloved. The result of such a childhood can readily be deduced. Those children who did manage to live till they were old enough to be apprenticed were coved and degraded to such an extent that they remained timid of manner and duIl of comprehension the rest of their natural lives.

The poor farm, we. say, was the first institution that Dickens exposed to his reading public. More than one person, we believe, was shocked at such a picture of misery so close to his own fireside. More than one heart ached, we are. sure, at the lot of the parish orphans; and we cannot help thinking that sone kindly people, more responsive to the suffering of those little loveless children than the rest, found thenselves lying awake at night, staring into the darkness, seeing pitiful little forms, and hearing weeping that needed not be. Dickens truly was accomplishing thru his novels what he could have done in no other way. Once the heart has been touched, the hands will do their part in alleviating suffering wherever it is found. Dickens had touched the heart.

Oliver's ninth birthday occasioned a visit from lir. Bumble, the parish beadle, and also a change in his manner and place of living. The child had now reached the age when it was customary to apprentice the orphans to some trade connected with the workhouse; consequentIy, Mr. Bumble had come to letch him for that purpose. In fact, that same night was board night when Oliver's future occupation was to be decided. With a hur- 


\section{1.}

ried goodbye to his shelter during most of his natural life, the boy left the farm, never to return. There was even a tinge of saciness to his leave-taking: for he knew he should not see his poor companions in misery again.

Dickens has given us a splendid description of the board in session the evening Oliver returned to his birthplace. me(oliver) had no time to think about the matter, however; for $\mathbf{I r}$. Bumble gave him a tap on the head, with his cane, to wake him up; and biding him follow, conducted him into a large whitewashed room, where eight or ten fat gentlemen were sitting around a table. At the top of the table, seated in an am-chair rather higher than the rest, was a particularly fat gentleman with a very round, red face.

'Bow to the board,' said Bumble. Oliver brushed away two or three tears that were lingering in his eyes; and seeing no board but the table, fortunately bowed to it.

'What's your name, boy?' said the gentleman in the high chair.

Oliver was frightened at the sight of so many gentlemen, which made him tremble; and the beadle gave him another tap behind, which made him cry; and these two causes made him answer in a very low and hesitating voice; whereupon a gentleman in a white waistcoat said he was a fool. Which was a capital way of raising his spirits, and putting him quite at his ease.

'Boy,' said the gentleman in the high chair,' listen

to me. You know you're an orphan, I suppose?"

"What's that, Sir?' inquired poor Oliver.

'The boy is a fool- I thought he was,' said the gentle- 
man in the white waistcoat.

'Hush!' said the gentleman who had spoken first.

'You know you've got no father or mother and that you were brought up by the parish, don't you?'

"Yes, Sir,' replied Oliver weeping bitterly.

'What are you crying for?' inquired the gentleman in the white waistcoat. And to be sure it was very extraordinary What could the boy be crying for?

'I hope you say your prayers every night,' said another gentleman in a gruff voice; and pray for the people who feed you, and take care of you-like a christian.'

'Yes, Sir,' starmered the boy. The gentleman who spoke last was unconsciously right. It would have been very like a Christian, and a marvellously gooo Christian, too, if oliver had prayed for the people who fed and took care of hirn. But he hadn't, because nobody had taught him.

'We11: You have come here to be educated, and taught a useful trade, 'said the red-faced gentieman in the high chair. 'So you'll begin to pick oakum tomorrow morning at six o'clock,' added the surly one in the white waistcoat. For the combination of both these blessings in the one simple process of picking oakum, Oliver bowed low by the direction of the beade; and was then hurried away to a large ward; where, on a rough hard bed, he sobbed himself to sleep. What a noble illustration of the tender laws of England: They let the paupers go to sleep!"

G.K. Chesterton says of Dickens that he "was anong other things a satirist, a pure satirist...Dotheboys Hall or 
Mr. Bumble's workhouse are exuberant satires on England." Certain it is that here is some of Dickens' finest satire and it continues with the rest of the account of the board meeting which we shall not quote, as the meeting was a lengthy one. However, as the outcome was to affect the fortunes of oliver very materially, we pause to make mention of one important matter of business that was disposed of. In view of the fact that the workhouse was "a regular place of public entertainment for the poorer classes; a tavern where there was nothing to pay; a public breakfast, dinner, tea, and supper all the jear round; a brick and mortar elysium, where it was all play and no worki", the board decided to diminish the quantity of food per capita to "three meals of thin gruel a day, with an onion twice a week, and half a roll on Sundays". 13

The above-mentioned regime was put into operation inmediately and was continued for six months. During this time Oliver and his workhouse companions, being growing boys and needing a large quantity of nourishment because of the fact, becane so desperate that they cast lots to see who would ask for more to eat at the next meal. The lot fell to oliver. The immediate result of his subsequent request was that he "was ordered into instant confinement, and a bill was next moming pasted on the outside of the gate, offering a reward of five pounds to anybody who would take oliver Twist off the hands of the parish." ${ }^{14}$.

12. Appreciations and Criticisms of the Works of Charles 13. Text, p. 13. 14. Text, p. 16 . 
Here in brief we have the second practice Dickens was desirous of bettering. The very atmosphere of the workhouse reeked with instances of glaring mismanegement. Many were the corpses placed in very mall pine boxes and lowered into premature graves because of privation and stark hunger. The board considered themselves above the level of their avowed inferiors and treated them as little better than brutes. The sorrows and hardships of the poor did not concern the board. They had only to see that the rules they laid down for the good of the parish, good from their viewpoint, were carried out. Hard labor, long hours, insufficient food, and countless miseries, all unmixed with the "milk of human kindness", characterized the workhouse of Dickens' time. These conditions the author exposed to his coterie of followers that they might be moved to some measure of reform. As Forster so aptly says, "It is the fact that teaches, and not any semonizing drawn from it."

In response to the afore-mentioned bill offering Oliver and five pounds to anyone who would take him, Mr. Gamfield, a chimney sweeper, presented himself before some of the members of the board. At that particular time he was in need of a small boy for register stoves, and also of the five pounds. 'It's a nasty trade,' said Ir. Iimbins, when Gamfield had again stated his wish.

- Young boys have been smothered in chimneys before now,' said another gentieman.

15. Iife of Dickens, John Forster, Abridged and Revised by George Gissing, p. 103 . 
'That's acause they damped the straw afore they lit it in the chimbley to malke 'em come down agin,' said Gamfield; 'that's all moke, and no blaze; vereas smoke ain't o' no use at all in making a boy come down, for it only sinds him to sleep, and that's wot he likes. Boys is very obstinit, and that's very lazy, gen'Imen, and there's nothink like a good hot blaze to make 'em come down with a run. It's humane, too, gen'Imen, acause, even if they've stuck in the chimbley, roasting their feet makes 'em struggle to hextricate theirselves.'.

"As Mr. Gamfield did happen to labour under the slight imputation of having bruised three or four boys to death already, it occurred to him that the board had, perhaps, in some unaccountale freak, taken it into their heads that this extraneous circumstance ought to influence their proceeaings."

After the board decided to allow Mr. Gamfield to apprentice Oliver, the gentleman in the white waistcoat made the fact known to him by saying, "Take him, you silly fellow! He's just the boy for you. He wants the stick, now and then; it'll do him good; and his board needn't come very expensive, for he hasn't been over-fed since he was born. Ha! ha! ha!" ${ }^{16}$

The atrocities comitted against children in the chimey-sweeping trade alone are almost unbelievable in this day and time, and Dickens was well aware of them all. Hayward infoms us of the indifferent attitude taken by most of the people of the time. 
"Pious women who attended Exeter Hall demonstrations and waxed hysterical over the sufferings of wooly-headed negroes five thousand miles away, not only permitted, but in many cases insisted upon, their chimneys being swept by little boys of five and six years old, because they kept the furniture cleaner than if brushes had been used.

The use of boys for chimney sweeping persisted, in spite of all legislation, until 1875, when constant deaths of children in flues aroused public opinion. Tet the horrors of the trade were so dreadful that as early as the callous days of 1817 agitation to secure its abolition had been made and constantIy renewed."

One instance of the horrible treatment to which these little children were subjected will suffice, although Dickens felt the question so strongly that he dealt with it again in Bleak House. (He dealt with many abuses more than once to impress their horrors upon his constituency the more indelibly.)

"In 1842 a case came before the Hull magistrates in which it transpired that a boy of ten had been sold five times, and though the injuries he had sustained in chimey clinbing had crippled him for life, he had been driven up no less than twelve flues a couple of days before the case came on." ${ }^{18}$

In 1834 an act had been passed whereby children to be apprenticed had to express their desire in the presence of two 17. The Days of Dickens, A. I. Hayward, p. 105.
18. The Days of Dickens, A. I. Hayward, p. 106. 
magistrates. Accordingly, Oliver was taken before two gentlemen of the law to make his declaration. Ho doubt Oliver's fate would have been settled then and there had not one of the gentlemen, being near-sighted and looking for the ink everywhere on his desk except directly in front of him, encountered the child's terror-stricken, tear-stained face. Ir. Bumble, having carefully coached his charge in the part he should play, had promised dire punishment if the boy deviated from the course laid out for him. Thruout the interview, the beadle's warning looks had restrained him from crying out. How, however, on being questioned, he burst into tears and begged to be allowed to do anything but be apprenticed to Mr. Gamfield. The old gentleman, a kindlyintentioned individual, bore out oliver in his request and refused to apprentice him.

It was not long, however, before Oliver was apprenticed, and that to the parish undertaker, Mr. Sowerberry. Although he did not realize it, he had barely escaped being put upon a tramp steaner as a cabin boy whose identity would have been effaced forever once he had left the shores of his native Ingland. Yet, nothing worse than Ir. Sowerberry's trade was in store for him at that particular time. It was dark by the time Mr. Bumble took his small charge to the undertaking establishment where he hoped to relinquish all claims upon him, in the name of the parish. They found the proprietor of the shop in the act of settling his accounts for the day by the light of a candle. After looking the child over, he called lirs. Sowerberry.

"IIy dear, "said Mr. Sowerberry, deferentially, "this is the boy from the workhouse that I told you of." Oliver bowed again. 
"Dear me!" said the undertaker's wife, "he is very sma11."

why he is rather small," replied Ir. Iumble; looking at Oliver as if it were his fault that he was no bigger; he is small. There's no denying it. But he'll grow, Mrs. Sowerberryhe'll grow."

"Ah! I dare say he will, " replied the lady pettishly, "on our victuals and our drink. I see no saving in parish children, not I; for they always cost me more to keep them than they're worth. However, men always think they know best. There: Get down stairs, little bag $o^{\prime}$ bones......

In this manner oliver entered upon his life as an apprentice. Fed upon the scraps that the dog refused, and put to bed among the coffins in the show-room, the child found new trials awaiting him at every turn. Death to most of us is something of which we stand in awe and dread. To Oliver, it became a hideous nightmare, while he was taken by his master and introduced to the seany side of the undertaker's trade. As he was small, and as he had an etheral expression on his young face, the child soon became one of his master's prize exhibits, a child mourner especially for children's funerals. In fact, before long he was very much in denand and had supplanted the funeral services of his master's assistant, a large charity boy named Woah Claypole. Woah resented the so-called favor thet Oliver had reached in Ir. Sowerberry's service, and, being a great deal larger than the child, treated him unmercifully when his master was out of sight. In fact, he was encouraged in his 
persecution of the boy by the attitude Irs. Sowerberry had assuried from the first and also by the expressed dislike of the serving girl, Charlotte, who doted on the charity boy and resented, like him, Oliver's seeming good fortune. ".....For many months he continued meekly to submit to the domination and ill-treatment of Ioah Claypole; who used him far worse than before, now that his jealousy was roused by seeing the new boy promoted to the black stiok and hat-band, while he, the old one, remained stationery in the muffin-cap and leathers." 20

One day lToah, in a particularly spiteful mood, began taunting Oliver about his mother. The child had stood his meanness a.II this time without murmering; but when his mother's memory was insulted, he jumped upon his tormentor and knocked him to the ground. Before long, however, Mrs. Sowerberry and Charlotte joined in the unequal battle and the orphan was locked in the cellar, while Moah went with all haste for Ir. Bumble. The memory of the beatings administered by the beadle and later by $\mathrm{Mr}$. Sowerberry that night remained with the child for many a day. His abuses having reached their culmination, Oliver detemined to run away the next day. Consequently, in the uncertain light of early morning he stealthily unfastened the door and slipped out into the dawn. Iife could surely hold nothing worse than it had so far, and the boy sincerely hoped it might hold something better. Oliver's days of apprenticeship were over, but the memory of the horrors he had endured lingered on. That year of abuse left its indelible mark on his young Iife that only the kindy ministrations of time could efface. 
Fere again Dickens was letting the fact teach, as he did throughout his novels, The trials of the child appeal to our sense of justice as no moralizing could ever do. We may be sure that those who read his story, heard the supplications of all the children of the Iondon poor. They saw countless throngs of boys and girls as well, apprenticed to masters of all trades, sold into a slavery from which there was no escape except thru death. The law looked on as these little ones suffered untold misery and anguish of body and soul, yet it offered no effective aid until some time later. Had Dickens been pemitted to live a little longer, he would have been enabled to see his cherished dreams for the children of the London poor coming true.

As we have glimpsed some of the evils surrounding the children of the city slums, causing them to lead lives of misery and pain, we have surely seen how Dickens was able to make his contribution to these children. Thru Oliver Twist he had exposed the conditions existing at the poor farm, in the workhouse, and during apprenticeship. Surely those who perused the story of the child were moved to action in alleviating the sorrow of countless children persecuted like himself. Surely they saw the evils of the parish manament through the life of young oliver and were constrained to demand better administration because of his sufferings. 
CHAPTER 2 


\section{Chapter II.}

\section{Poor Smike, the Nameless Drudge.}

During the months from April, 1838, to October, 1839,

Dickens published his second novel of purpose, Micholas Mickleby, a protest against the Yorkshire schools. That education in Ingland was at a. Iow ebb at this time, and, in fact, even to the present century is well known. Conditions existing in the schools, the curricula, the teachers' qualifications, all were in an almost hopeless state. Mrs. Peel in her A Hundred Wonderful Years, 1820-1920, reporting the findings of a comission in 1861 under the Presidency of the Duke of Irew-Castle says that it received "distressing evidence as to the character of most of the private schools, which were usually the ones to be found in the districts whose need was attracting special attention. These were often taught by discharged servants or barmaids, outdoor paupers, small traders, washerwornen, cripples, arunkards, consumptive and very aged persons-" those, in short, who had no more profitable resource than such a school afforded. Iany of the schools were kept in lofts, bedrooms, cellars, kitchens, shops, workshops, or other available but unsuitable places; where the children, generally little more than infants, tumbled over one another like puppies in a kennel...."

All of Dickens' biographers agree that the author was dealing with the Yorkshire schools in Nicholas Mickleby. Most of his biographers refer to his pilgrimage to Yorkshire for the purpose of ascertaining the exact state of affairs existing in the schools there. F. G. Kitton in his Charles Dickens mentions the fact when he says: 
"As in oliver. Iwist the Novelist exposed the shortcomings of the Poor Law system, so he determined to make "Micholas Nickleby" the medium for calling attention to the horrors of cheap boarding schools in Iorkshire. Of these institutions he had heard dreadful accounts in his boyhood, and these so stirred his emotions that he seized the opportunity now afforded him of investigating the subject. In January, 1838, with this special object in view, he and his artist friend, Hablot K. Browne, journeyed by coach, in severe winter weather, to the locality where schools of the worst repute were situated. Forewarned that the Yorkshire pedagogues might resent, for obvious reasons, his sudien appearance in theirmidst, Dickens consulted a solicitor friend (Ir. Smithson) who had a Yorkshire connection, and between them a 'pious fraud' was concocted in the form of letters of introduction having reference to "a suppostitious little boy who had been left with a widowed mother' anxious to place him at a school in the neighborhood, one of these missives being addressed to a certain individual who subsequentIy appeared in the story as honest John Browdie. Information thus gathered considering typical boarding schools near the border Iine of Yorkshire and Durham enabled the novelist to arrive at definite conclusions regarding the manner in which such seminaries were conducted and to depict, with consummate force and skill, the memorable scenes at Dotheboys Hall which, though but 'a faint and feeble pictures of an existing reality' (as the author himself characterized them), so strongly excited public indignation that the particular institutions so justly denounced by him were doomed to rapid extinction." 
In Dotheboys Hall then, Dickens has given us a typical Yorkshire school. We are introduced to the schoolmaster, Ir. Wackford Squeers, at a coffee room where he was waiting for students to apply for entrance into his establishment. To beguile the interim, he was bullying a small boy who had been entrusted to his care; but, on the announcement of a caller, he changed his tone. The visitor, Mr. Snawly, heard these words as he entered." "...At the delightful village of Dotheboys, near Greta Bridge, in Yorkshire, where youth are boarded, clothed, booked, washed, furnished with pocket-money, provided with all necessaries--."

On being introduced, the gentleman said, "The gentleman...that advertised in the Times newspaper?"

"Yoming Post, Chronicle, Herald, and Advertiser, regarding the Academy called Dotheboys Hall, at the delightful village of Dotheboys, near Greta Bridge, in Yorkshire," added Nr. Squeers.

A little later he continued, WVvery wholesome luxury, Sir, that Yorkshire can afford,...every beautiful moral that Irs. Squeers can instill, every- in short, every comfort of a home that a boy could wish for, will be theirs, Mr. Snawly." ${ }^{23}$

From Ir. Squeers' advertisement, we would expect a splendid school. Yet he admits later to Micholas Mickleby some of his deceit.

"The fact is, it ain't a hall," observed Squeers, dryly. "Oh, indeed!" said Nicholas, whom this piece of intelligence much astonished.

23. The Iife and Adventures of Micholas Nickleby, Charles Dickens in two volumes, F. Jelson \& Sons, Lta., London, Undated, p. 36 .

(This text will be used throughout this chapter.) 
alo," replied Squeers. "We call it a Hall up in Iondon, because it sounds better, but they don't know it by that name in these parts. A man may call his house an island if he likes; there's no act of parliament against that, I believe?"

Ware, in his Bducational Reform states, "...There are not a few (schools), often conducted by men or women who should know better, which, with apparent intent to mislead, assume high-sounding titles, causing credulous parents to believe that within their walls their children may receive an education even higher than secondary."

Kitton tells us that there is some controversy over the exact school in Yorkshire that Dickens designated as Dotheboys Hall. However, he adds that evidence leads him to suppose "Dickens had in mind a particular Yorkshire school and its master, namely Bowes Academy, kept by William Shaw, whose advertisement, among others of a similar character, may be found in contemporary issues of the Iines, as follows:

'EDUCAIION. - By Ir. Shaw, at Bowes Academy, Greta Bridge, Yorkshire, YOUTH are carefully INSTRUCTED in English, Iatin, and Greek Ianguages, Writing, Comon and Descimal Arithmetic, Book-keeping, Iensuration, Surveying, Geometry, Geography, and Tavigation, with Board, Clothes, and every necessary, at 20 guineas per annum each. No extra charges. No vacations. Further particulars may be known on application to Ir. J. Ietcalfe, agent, 38 Great Marlebone Street. Ir. Shaw attends at the George and Blue Boar, Holbom, from 12 to 2 daily." 
A little later, Kitton continues, "...but corroborative evidence of the identity of Squeers is afforded by the Movelist's note-book, where, under date of February 2, 1838 , he enters the following memorandum:-

'Shaw, the schoolmaster we saw to-day, is the man in whose school several boys went blind some time since from gross neglect. The case was tried and the verdict went against him. It must have been 1823 and 1826. Look this up in the newspapers. ${ }^{26}$

lay we be allowed to add that W. S. might stand for William Shaw as well as for Wackford Squeers? Dickens sometimes used the initials of the name of a person he knew for the first letters of the name of one of his characters.

Let us consider some aspects of Dotheboys Hall as portrayed for us by Dickens.

Regarding the requirements for entrance, Mr. Snawley asks, "Up to what age do you keep boys at your school then?" "Just as long as their friends make the quarterly payments to my agent in town, or until such time as they run away," replied Squeers.

In other words, the only requirement for entrance was prompt payment on the part of those responsible for the child's being placed in the school. There was no age limit. Regardless of how young or how old the boy was, he was still eligible. Regardless of his mental qualifications or of his schooling until his advent at the hall, he was welcome, as long as his tipend was paid regularly, or, Mr. Squeers added, until he ran away. Appar26. Charles Dickens, F. G. Kitton, pp. 62 and 63. 
ently the schoolmaster was very anxious to receive the money paid for each pupil. The children and their education were merely means to an end, necessary evils to be coped with in order that he might receive the consideration for their care. As for the equipment each child was supposed to take with hin to the hall, Ir. Squeers tells us:

"... Each boy is required to bring, sir, two suits of clothes, six shirts, six pair of stockings, two night caps, two pocket handkerchiefs, two pair of shoes, two hats, and a razor." The incongruity of these personal effects is obvious. Two handkerchiefs would never suffice, and a razor would certainly be unnecessary for a child. It appears that Squeers was looking after his own personal interests as well as after those of his protégés.

We may add in passing that the children were allowed to write home only once or twice a year, the letter to be a copy of a circular prepared by the schoolnaster saying "they never were so happy, and hope they may never be sent for."

As this chapter really centers around poor smike, a child brought up at Mr. Squeers' school, we shall endeavor to show the results of the system thru his life. Although Smike has reached the age of about eighteen or nineteen, he has been at the school since he was about six, and, consequently, is a worthy representative of the effect of Ir. Squeers' instructions. Nicholas Nickleby, the new teacher at Dotheboys Hall, gives us his impression of Smike. 
"Although he could not have been less than eighteen or nineteen jears old and was tall for that age, he wore a skeleton suit, such as is usually put upon very little boys, and which, though most absurdly short in the ams and legs, was quite wide enough for his attenuated frame. In order that the lower part of his legs might be in perfect keeping with his singular dress, he had a very large pair of boots, originally made for tops, which might have been once worn by some stout farmer, but were now too patched and tattered for a beggar. Heaven knows how long he had been there, but he still wore the same linen which he had first taken down; for round his neck was a tattered child's frill, only half concealed by a coarse man's neckerchief. He was lame; and as he feigned to be busy in arranging the table, glanced at the letters with a look so keen, and yet so dispirited and hopeless, that Iicholas could Hardly bear to watch him.

'Have you-did anybody-has nothing been heard-about me?' inquired Smike.

\section{'Devil a bit,' replied Squeers testily. \\ 'ITot a word,' resumed Squeers, 'and never will be.} Now this is a pretty sort of thing, isn't it, that you should have been left here all these jears and no money paid after the first six-nor notice taken, nor no clue to be got who you belong to? Its a pretty sort of thing that I should have to feed a great fellow like you, and never hope to get one penny for it, isn't it?'

The boy put his hand to his head as if he were making an effort to recollect something, and then, looking vacantly at his questioner, gradually broke into a smile, and limped away. ${ }^{2}$

Poor Smike was the nameless drudge of Dotheboys Hall. Brought there at an early age by some gentleman, whose name Mr. Squeers no longer remembered, the boy had borne the brunt of most of the meanness his master had been able to conjure up. As his origin was unknown, his very name being one given him by his guardian to efface his identity, he had existed during some 29. Text, Vol. 1, pp. 84 and 85. 
twelve years under the heartless supervision of the hall. Abused in every way possible, he bore evident marks of his sufferings. Even Ins. Squeers admitted that he was growing silly; and his wasted fom and pronounced limp were mute witnesses to the pain and misery he had borne. Yet, withal, he always looked forward to some news from his unknown guardian, news that might prove to bring about his freedom from the weary bondage of the hall. With nothing to lighten his sad existence but curses and cuffs, poor smike was a pathetic figure, the product of the heartrending system employed by Ir. Squeers.

As we can well imagine, the equipment of the school was in keeping with the system that we have indicated. Outwardy, Dotheboys Hall "was a long, cold-looking house, one story high, with a few straggling out-buildings behind, and a barn and stable adjoining." Certain it is that the appearance of the house was a far cry from the institution described so vividly by $l[r$. Squeers in the Iondon newspapers. Inside the building, the two rooms which Dickens described for us were in keeping with the general air of dilapidation. The first one, he tells us, "was a small parlour scantily furnished with a few chairs, a yellow map hung against the wall, and a couple of tables, one of which bore some preparations for supper, while on the other a tutor's assistant, a Iurray's grammar, half a dozen cards of tems, and a worn letter directed to Wackford Squeers, Esquire, were arranged in picturesque confusion. ${ }^{31}$ The second one, he informs us, "resolved itself into a bare and dirty room, with a couple of windows, where of a tenth part might be of glass, the remainder be- 
ing stopped up with old copy-books and paper. There were a couple of long, old, rickety desks, cut and notched, and inked, and damaged in every possible way; two or three forms; a detached desk for squeers, and another for his assistant. The ceiling was supported, like that of a barn, by cross beans and rafters; and the walls were so stained and discoloured that it was impossible to tell whether they had ever been touched with paint or whitewash."

The courses of instruction at the hall were unique. Consistent with the atmosphere of the school and also with Mr. Squeers' methods of force, we cannot expect that the training was either thorough or in accord with the rules of pedagogy. Dickens describes one day's lessons for us in Nicholas Mickleby. Let us look at the first class, taught by Mr. Squeers, the schoolmaster. It consisted of about half a dozen boys dressed in tom and filthy clothing, among whom there was one text book, very much the worse for wear.

"This is the first class in English spelling and philosophy, Nickleby, ' said Squeers,...'-Now, then, where's the first boy?"

'Please, sir, he's cleaning the back parlour window,' said the temporary head of the philosophical class.

'So he is, to be sure,' rejoined Squeers. 'We go upon the practical mode of teaching, Nickleby- the regular educational system. C-I-e-a-n, clean, verb active, to make bright, to scour. W-i-n, win, d-e-r, der, winder, a casement. When the boy knows 
this out of a book, he goes and does it. It's just the same principle as the use of globes. - Where's the second boy?'

'Please, sir, he's weeding the garden,' replied a

smali voice.

'To be sure,' said Squeers, by no means disconcerted. 'So he is. B-o-t, bot, $t-i-n$, tin, bottin, n-e-y, ney, bottiney, noun substantive, a knowledge of plants. When he has learned that bottiney means a knowledge of plants, he goes and knows

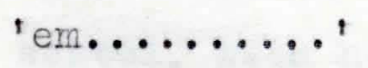

'Third boy, what's a horse?'

'A beast, sir,' replied the boy.

'A horse is a quadruped, and a quadruped's Iatin for beast, as everyone that's gone through the gramar knows, or else, where's the use of having grammar at all?'

'Where, indeed!' said Iicholas, abstractedly.

'As you're perfect in that,' resumed Squeers, turning to the boy, 'go and rub down my horse, and rub him down well or I'Il rub you down. The rest of the class go and draw water up, till somebody tells you to leave off; for its washing day tomorrow, and they want the coppers filled. " $^{33}$

After the first class had been dismissed, Nicholas Nickleby took his first group of boys in reading, about fourteen children, ragged and unkempt like those in the first class, and practically untaught in that branch of learning. There was no distinction paid to those boys who had learned a little and those who were starting into school for the first time. When 
the period for reading arrived, they all read together. In fact, the whole morning passed with the children in Nicholas, group having had only one class. Duxing that time the other children were engaged in the afore-mentioned occupations. As there were only half a dozen dog-eared books for the whole school, the boys made no preparation for their recitations. In fact, they, doubtless, never knew what classes they woulo have from one day to the next. With no attempt at grading the school, with no preparation on the part of the pupils, and with Ir. Squeers' experimental means of instruction, we can readily see the result of the system. Mo wonder poor Smike was dull and slow of comprehension. Whatever pretense of instruction Ir. Squeers made, Smike had Iong ago outgrown so that he never attended classes. He was the Jack-of-all-trades for everyone connected with the institution. All of the jobs that no one wanted to perform vere thrust upon him; and if they were not well done, or if Mr. Squeers happened to be in a particularly savage mood, poor Smike suffered the consequences in the form of terrible beatings. The master was taking out in beatings the equivalent of the money that should have come to him for the boy's expenses at Dotheboys Hall.

The school was run on a systern of strict economy as Ir. Squeers was a frugal man who stretched every penny to its farthest capacity. There were many ways in which a schoolmaster could save, even though, as a result, his pupils were discomfited by his thrifty nature. We have already alluded to the matter of textbooks, there being only about half a dozen for the whole school. In the matter of domestic comforts, there was extensive 
saving. No fewer than four boys slept in one bed, the bed being designated as that belonging to one of the four. The same number of boys shared a single towel so that the washing might be less. The amount of water was limited as it had to be drawn from the well, which not infrequently froze over in the winter. Then personal habits of cleanliness were dispensed with until the ice was broken. Irr. Squeers was careful to work for the best interest of his young son, Wackford Junior. Usually these interests consisted of outfitting him from the equipment required of all the pupils in the school. Anything in the nature of clothing belonging to the new boys that Wackford could possibly wear, his father gave him. The rest of the clothing brought by them was put away. Attired in the cast-offs of former pupils, the boys wondered what had happened to the clothing they had brought, that is, unless they saw young squeers attired in it. The most rigid economy was practiced in the diet furnished to the boys. As Mrs. Squeers was anxious to cut down the ration allotted to each child to the minimum, she contrived a disgusting scheme to ruin the children's appetites and cause them to eat less than they would otherwise have been allowed. Very often, before breakfast, she had them march past her so that she could force into their mouths a large spoonfuI of sulphur and molasses. As the punishment of resisting was dire, the boys evinced their hatred of the stuff only by grim faces. Mr. Squeers stood ready with his cane to check any further remonstrance. After swallowing the horrible doses administered by Iirs. Squeers, the boys filed out into another room where they were given a bowl of a horrible brown mixture and a small wedge of bread with which to eat it, in lieu of a spoon. 
Dinner consisted of some stir-about, potatoes, and hard beef. Late in the afternoon, the last meal of the day was served, consisting of bread and cheese. Scurvy was one of the diseases contracted because of such a deficient diet. No wonder Smike was so thin he could wear the clothes he brought with him as a child. That he had existed so long seems incredible, as the food he had received contained practically no nutritive value.

As for the other children, they were in a pitiful state too, but not one had been at the school so long as Smike. Consequently, he suffered from the ill effects of his treatment more than did the others. Dickens says there were:

"Pale and haggard faces, lank and bony figures, children with the countenances of old men, defomities with iron upon their limbs, boys of stunted growth, and others whose long, meagre legs would hardly bear their stooping bodies, all crowded on the view together; there were the bleared eye, the hare lip, the crooked foot, and every ugliness or distortion that told of unnatural aversion conceived by parents for their offspring, or of young lives which, from the earliest dawn of infancy, had been one horrible endurance of cruelty and neglect. There were little faces which should have been handsome, darkened with the scowl of sullen, dogged suffering; there was childhood with the light of its eye quenched, its beauty gone, and its helplessness alone remaining; there were vicious-faced boys, brooding with leaden eyes, like malefactors in a jail; and there were young creatures on whom the sins of theirfrail parents had descended, weeping even for the mercenary nurses they had known, and lonesome even in their loneliness, with every kindly sympathy and affection blasted in its birth, with every young and healthy feeling flogged and starved down, with every revengeful passion that can fester in swollen hearts eating its evil way to their core in silence, what an incipient Hell was breeding there." 34

These were the "young nobleman" that Squeers had advertised in Iondon. Poor little waifs they were, most of them unloved and unwanted. Dotheboys Hall sheltered illegitimate children and little ones crippled and maimed whose parents wished to get rid of them in the most humane manner possible. Snawley, when he 34. Text, Vol. I. p. 94. 
entrusted his two step-sons to Squeers, asked particularly that they. write only occasionally and that they never have a vacation. In other words, he wanted them to lose their identities, as far as he was concerned. Smike was truly a typical representative of the school in that he was lame, dull of understanding, wasted away in body, and of uncertain parentage. When Squeers paid his semi-annual visit to Iondon, it was customary for him to bring back messages and letters from the boys' parents and guardians. The day after he returned, he called the boys together and read the letters to them. Any enclosures, such as clothes or money, he confiscated, telling the children he would keep their property for them. Meedless to say, they never saw it again. It was also customary for him to bestow a particularly hard whipping upon one of the boys as an example to the others. On the particular day Dickens described, the schoolmaster flogged a child unmercifully because he had warts on his hands.

Poor Smike, after all these years, found a friend in Micholas Nickleby. There had never been anything beautiful in his life till now, but this friendship softened, in part, the sufferings of his childhood. With the coming of the new teacher, his wrongs had reached their climax, since squeers treated him worse than ever because of licholas' having befriended him. As if his endurance had suddenly snapped, Smike, without a word to anyone, ran away. We can imagine how great was the consternation when his absence was detected! After a prolonged search, he was brought back and the school was ordered to assemble to witness his punishent. With a whip purchased for the purpose, Squeers struck the boy a terrible blow. At the sound of the 
impact of the whip against poor Smike's body, all the horrors Micholas had witnessed during his stay at the school suddenly flashed across his mind. At a bound, he found himself in possession of the whip, taking out all his pent-up wrath in great blows that leveled the schoolmaster to the ground in a writhing heap. When he was tired, Nicholas threw down the whip, packed his clothes, and left the school forever. As he had very little money with him, he lay down on the hay in a barn to sleep that night, his long walk having tired him considerably. When he awoke the next morning with the first roys of the sun, he found snike asleep near him. The faithful boy had followed the only friend he had ever had. All day he had kept just out of Nicholas' sight, intending to slip away before his comrade awoke in the morning. He had left the nightmare of his boyhood and started out on a new adventure. Yet, the horrors of those years, the terrible punishments he had endured, the hunger and privations lingered on to cast their lengthening shadows over the rest of his short life.

We receive only one more glimpse of Dotheboys Hall in Micholas Mickleby. By that time, poor smike has been buried in a premature grave, the result of the horrors of his years at the institution. At the end, he was a little child again, seeing the faces of the children who were there in his childhood. Thus died one of the helpless victims of Squeers' deleterious system. Yet there were not destined to be many more horrors enacted at the institution; for Squeers was put in prison for fraud, and, in consequence, the school was broken up. Some of the parents came to recover their charges. Those children who were left ran away, 
although some of the younger ones went only a short distance, where they were found and returned to the hall. Bventually, all the children were taken away, and the school fell into disrepute.

Thus we see in Niclolas Mickleby another of the evils that Dickens was fighting in his crusade against the wrongs little children were subjected to during the nineteenth century. In all, Hughes tells us, he dealt with twenty-eight schools in his novels; conseguently, we see the importance in which he held the question of education and educational refom. However the worst type of school he had to deal with is the school of Mr. Squeers, Dotheboys Hall, really Do-the-boys HaIl. He has shown us how Ir. Squeers had as his purpose to "do-the-boys" in every way he could. All the fruits of the system were the opposite of those that should be desired. Iean bodies, befuddled minds, aching and rebellious hearts, these were the products of the institution. There was none of the joyous lightheartedmess of childhood the author so wished to see. Only cowed and browbeaten little waifs of humanity, old and worn long before their time came out of the school. In poor Smike, we have the culmination of the horrors of Mr. Squeers system. No wonder Dickens was so anxious to drive the Yorkshire schools out of existence. Yet, as in all of his novels, he did not moralize. He gave us the facts and let them teach. All over Ingland, people read the pathetic story of Smike, and we feel confident that the sentiment his story aroused brought about in part the breaking up of the terrible Yorkshire schools and the subsequent reforms in education during the following decades. 35. Dickens as an Educator, James I. Hughes, p. 2. 
CHAPTER 3. 
Iittle Dorrit, the Child of the Irarshalsea.

Another abuse that Dickens was anxious to obliterate was the debtor's prison, an institution of long standing. In fact, so long had it been a part of the English administration of law that it had come to be looked upon as a necessary appendage of justice. The Encyclopedia Britannica tells us:

"At this time prisons were primarily places of detention, not of punishment, peopled by accused persons, still innocent in the eyes of the law, and debtors guilty only of breaches of the financial rules of a commercial country, framed chiefly in the interest of the creditor. Freedom from arrest was guaranteed by Iagna Charta, save on a crininal charge, yet thousands were committed to gaol on legal fictions and retained inderinitely for costs far in excess of the original debt. The inpecunious were locked up and deprived of all hope of eaming means to obtain enlargement; while their families and persons dependent on them shared their imprisonment and added to the overcrowding. The prisons were always full. Gaol deliveries were of rare occurrence; even when tardy trial ended in acquittal release was delayed until illegal charges in the way of fees had been satisfied. ${ }^{3}$

John Howard in his report of the prisons at the end of the eighteenth century states "that they were for the most part pestiferous dens, overcrowded, dark, foully dirty, not only illy ventilated, but deprived altogether of fresh air. The wretched inmates were dependent for food upon the caprice of their gaolers or the charity of the benevolent; water was de- 
nied them except in the scantiest portions; their only bedding was putrid straw. Every one in durance, whether tried. or untried, was heavily ironed. All alike were subject to the rapacity of their gaolers and the extortions of their fellows. Gaol fees were levied ruthlessly- 'garnish' also, the tax or contribution paid by each individual to a common fund to be spent by the whole, generally in drink. Idleness, drunkenness, vicious intercourse, sickness, starvation, squalor, cruelty, chains, awful oppression, and everywhere culpable neglect - in these words may be summed up the state of the gaols at the time of Howard's visitation." By the year 1812, J. Neild tells us that the prisons were not improved. 37 That Dickens was familiar with the conditions existing in the English prisons is well known, as his father was incarcerated in the liarshalsea in 1822 for insolvency and remeined there during several months. In David Copperfield, the author dealt with the life and habits of his father duning these months; although Nr. Micawber, who is in reality Mr. Dickens, was placed in King's Bench Prison. Yet the Marshalsea is the prison described. The King's Bench was for prisoners who were there for a long period of time; for that reason it was regarded as more fashionable than the Marshalsea, which received prisoners for a supposedy short term of confinement. Political offenders and prisoners of note usually found themselves at the King's Bench, but the more humble Marshalsea received the obscure persons indebted to a small extent. 
Such an impecunious gentleman was lir. Dorrit. Finding himself forced to retire to the Msrshalsea for a shont period, he brought only a portmantau as he expected to be out immediately. He did not. consider it necessary that he unpack his belongings "he was so perfectly clear- like ali the rest of them, the turnkey on the lock said-that he was going out again directly."

The Encyclopaedia Britannica tells us, in discussing the whole subject of Bankmuptey, that:

$$
\text { "Under the act of } 1849 \ldots \ldots \ldots \text { a deed of arrangement }
$$
executed by six-sevenths in number and value of the creditors for 10 pounds and upwards should be binding upon a.11 the creditors without any proceedings in or supervision by the court." Consequently, Mr. Dorrit was preseint at a meeting of his creditors to straighten out his financial difficulties. Regarding his affairs, Dicliens tells us:

"The affairs of this debtor were perplexed by a partnership, of which he knew no more than that he had invested money in it; by legal matters of assignment and settlement, conveyance here and conveyance there, suspicion of unlawful preference of creditors in this direction, and of mysterious spiriting away of property in that; and as nobody on the face of the earth could be more incapable of explaining any single item in the heap of confusion than the debtor himself, nothing comprehensible could be made of his case. To question him in detail, and endeavor to reconcile his answers; to closet him with accountants and shamp practitioners, learned in the wiles of insolvency and bankruptcy; was only to put the case out at compound interest of incomprehensibility. The irresolute fingers fluttered more and more ineffectually about the trembling lip on every such occasion, and the sharpest practitioners gave him up as a hopeless job." 40

38. Iittle Dorrit, Vol, I, p. 65, from The Works of Charles Dickens in. Thirty Volumes, N. Y., undated. This text wi11 be used throughout this chapter.

39. The Encyclopaedia Britannica, Vol. III, p. 323.

40. Itttie Dormit, Charies Dickens, p. 67. 
Nothing could be made of the tangle of his affairs, so that he remained at the Marshalsea for a period of twenty-five years, forgotien, to all intents and purposes, by those very persons who had had him placed there. His was an unusual case to be sure, but it was not an impossible case. The laws dealing with Bankruptey and Insolvency were vastly inadequate, and it took the rest of the nineteenth century to change them into something like efficiency.

The Marshalsea Prison where Mr. Dorrit was sent for debt is very vividiy described by Dickens:

"It was an oblong pile of barrack building, partitioned into squalid houses standing back to back, so that there were no back rooms; environed by a namow paved yard, hemmed in by high walls duly spiked on top. Itself a closé and confined prison for debtors, it contained within it a much closer and more confined jall for smugiers. Offenders against the revenue laws, and defaulters to excises of customs, who had incurred fines which they were unable to pay, were supposed to be incarcerated behind an iron plated door, closing up a second prison, consisting of a strong cell or two, and a blind alley some yard and a half wide, which formed the mystemious temination of the very limited skittleground in which the Marshalsea debtors bowled down their. troubles." 41

Into such environment Little Domit, the child of the Marshalsea was welcomed. Lying on her poor bed, Mrs. Domit awaited the miracle of birth. The heat, which was sufficiently suffocating throughout the whole city, seemed to be accentuated there in the stifling prison room whose walls effectually held it and concentrated it. Mrs. Bangham, the selfappointed mid-wife, hovered near, waving a cabbage leaf in the sultry air both to keep the flies from annoying her patientIf that could be, as the walls were covered with them- and to stir the humid atmosphere a little by the motion. The doctor whom she called was a typical inmate of the institution, en- 
gaged at that time, as at most times, in smoking his pipe and imbibing freely of brandy. He was "amazingly shabby, in a torn and darined rough-weather sea-jacket, out at the elbows and eminently short of buttons (he had been in his time the experienced surgeon carried by a passenger ship), the dirtiest White trousers conceivable by mortal man, carpet slippers, and no visible linen". During his ministrations to the sick woman, he partook of brandy at intervals and forced Mrs. Bangham to do likewise. After several hours of waiting, the baby arrived; and the doctor had returned to his shabby apartment, very much the worse for the brandy, and for the money that wr. Dorrit had acequired by a hasty visit to a pawn shop on the part of Mrs. Bangham,

By the time that Amy Dorrit had arrived at the age of eight, her frail mother died, probably because of the prison Iife as mch as because of inherent weakness. Then Amy became the real head of the Dorrit family, as her father grew grayer añd more resigned to his cloistered life on account of his sorm row. It was at that time that certain facts became evident to the child of the Marshalsea. As her special friend she had. chosen the turnkey who gradually took the place of her preoccupied father. Many happy hours passed by, with the child listening wide-eyed to the stories the old man could tell her. On one particular occasion, after listening to some of his tales, the child asked him some questions that apparently had been puzzling her for a long time.

"Thinking of the fields," the turnkey said once, after watching her, "ain't you?" 
"Where are they?" she inquired.

"Why, they're -over there, my dear," said the turnkey, "with a vague flourish of his key. "Just about there."

"Does anybody open them and shut them? Are they

locked?"

The turnkey was discomfited. "Well," he said, "Not in general".

Finally she asked if her father and the other prisoners were sorry that they could not go over to the fields. At that question, the old man changed the subject.

The child had reached the age when all children ask their parents to explain the puzzling problems of life; and Bob, the turnkey, felt that he could not cause her the pain of knowing the real situation of the prisoners. Yet the child, born and reared in the prison atmosphere, somehow sensed the answer to the very questions Bob had so carefully evaded. The feeling that the debtors were situated differently from the rest of the people of Iondon was gradually taking form in her young mind. Yet, the turmkey was not to be outdone by the machinations of fate. Nany sundays in the pretty weather, he and his young friend sallied forth from the grim, old Marshalsea to spend hours in the fields that they so admired from over the forbiding spikes of the prison. For a time at least the child's queries were silenced, as she played in the green grass and gathered bouquets of flowers to carry back with her into the walls of the prison.

The poor little children of these prison families suffered even more rigid hardships than their parents; for were they not innocent, yet confined within the prison walls? 
There being no money for their support outside the Marshalsea, they were forced to spend the time of their fathers' incarceram tion there with him. Iike Iittle Dorrit they grew pale and wan from lack of fresh air and exercise, from deficient diets, and exposure to cold and heat alike. Their clothing being of the scantiest afforded poor protection against the London fogs and mists, Comforts were few in their constricted lives. Yet, withal, the system of imprisonment for debt to which their parents were subjected really included them, as there was no place where they could be left until the sentence had been served. Poor little children, the humiliation of their situations made thentimid and shrinking, instead of naturally boisterous. Dickens knew the horrors of those months of his father's stay at the Marshalsea. He felt within himself the shame of his position as the son of a prisoner and carefully guarded his secret against the prying eyes of the world much as Iittle Dorrit kept from the Clennams the secret of her life there. Soon Amy reached the age of thinteen, and with it, womanhood. As time passed, her father had grown to depend upon her more and more, as did her brother and sister also. Although the youngest, she was forced to become the head of the family by virtue of the fact that no one else would accept that responsible position. Not only had she managed a little schooling for herself, but also had arranged some spasmodic education for her sister and her brother during some three or four years. Now she was ready to give them some vocational training. It so happened that a dancing-master found his way to the prison at the crucial moment, a man who pitied poor little Amy and was glad to be of service.to her. The result of his kindness was a course of dancing lessons for Amy's sister, Fanny. At 
the end of ten weeks, the dancing-master was released, and Fanny was able to find a position outside the prison as a dancer in a small theatre where her uncle played the clarionet. Then a milliner came into the lrarshalsea, kindhearted and patient like the dancing-master, who gave the child lessons in sewing so that she became a proficient needle-woman. Then, she too, found employment outside the walls and helped to support the family. Her efforts on her brother's behalf proved useless, as he never stayed at any one place long enough to learn the first principles of the business. How many jobs tip was employed in we do not know; but his shiftless nature soon showed itself and he was enjoying idleness as before. At length he became a prisoner too, although his kindly sister kept the knowledge from his father. That the Dorrits were fortunate in having such an ambitious sister and daughter is obvious. The families of many of the prisoners had no opportunity of earning any money whatsoever, and they were almost desperate both during their incarceration and after their release. Many of them depended on the kindness of their friends for food and clothes; and when these were not forthooming, they went ragged and hungry. Employment within the prisons was not usual. The debtors were there to await their release, not to earn a living. Consequently, it was customary for those who had any resources whatsoever to spend their time carousing, playing cards, or bowling, when the weather permitted. Drunkenness, with its attendant evils, was prevalent. Visitors to the fail found themselves besieged with requests for money. The debtors were veritable beggars. Even those who would have shrunk from the practice before entering the institution had re- 
course tö it before long, stifling thein qualms with their

- daily needs of sustenance.

\section{Perhaps one of the most degrading practices con-}

nected with the whole system was that of permitting "go-

betweens" the freedom of the prison so that they coild carry

on their degrading business. Did one need to pawn a watch,

a ring, a piece of family plate? His only recourse was to the "go-betweeners" wo transacted. the business and rept a Iiberal commission for their part in the affair. Often they made purchases for the prisoners, usually of food, tobacco, or wines, always keeping out their share of the money given them for the commodities. Dickens gives us a lumid picture of these people as the gates opened in the monning and they hurried in apologetically to consult their patrons or bring them their purchases.

"There was a string of people already straggling in, whom it was not difficult to identify as the nondescript messengers, go-betweeners, and errand-bearers of the place. Some of them had been lounging in the rain until the gate should open; others, who had timed their amival with greater nicety, were coming up now, passing in with damp whitey-brown paper bags from the grocers, loaves of bread, lumps of butter, eggs, milk, and the like. The shabbiness of these attendants upon shabbiness, the poverty of these insolvent waiters upon insolvency, was a sight to see. Such threadbare coats and trousers, such fusty gowns and shawls, such squashed hats and bonnets, such boots and shces, such umbrellas and walking-sticks, never were seen in Rag Eair. A.1 of them wore cast-off clothes of other men and women; were made up of patches and pieces of other people's individuality, and had no sartorial existence of their own proper. Their walk was the walk of a race apart. They had a peculiar way of doggedly slinking round the corner, as if they were etemally going to the pawnbroker's. When they coughed, they coughed like people accustomed to be forgotten on door-steps and in draughty passages, waiting for answers to letters in faded ink, which gave the recipients of those manuscripts great mental disturbance and no satisfaction. As they eyed the stranger in passing, they eyed him with borrow ing eyes - hungry, sharp, speculative as to his softness if they were accredited to him, and, the likelihood of his standing something handsome. Mendicity on commission stooped in their high shorlders, shambled in their unsteady legs, buttoned and pinned and darned and dragged their. clothes, fraved their button-holes, 
issied from their mouths in alcoholic breathings." Meantime, the Eather of the Marshalsea, as Wr. Dorrit had come to be called because of the length of his abode at the prison, steadily deteriorated. As he grew older, he became more childish and querilous, demanding more and more of Any's time. He was easily imitated, and increasingly more difficult to manage. Punctuality of meals was one point on which he was obdurate. Another particular he expected consideration in was his pretense to respectability. Never would he tolerate the suggestion that his daughters worked outside the prison. Rather, they had to keep up a farce with him, pretending that they needed a change from the prison routine. At all times, he emphasized the fact that he was once a gentleman and that he was rearing his children in genteel manner. Perhaps the most embarrassing of his peculiarities was his thinly veiled hints for money. That his daughter, Amy, whom her friends called "Little Dorrit", was exceedingly humiliated can well be imagined, He called the alms he received "testimonials", a kind of recognition by friends and by some of the prisoners of his position as Father of the Marshalsea. Sometimes he indicated the size of the gift he expected by a reminiscence, real or imaginary, conceming some testimonial of the proper amount, other times, he casually left a small amount of money on the table by way of a reminder. On sunday, the regular visitors' day, the small sum often increased as the afternoon wore on. If a visitor from whom the old man expected a large gift failed to leave it, Mr. Dorrit talked about his stinginess after he had gone and greeted him coldly when he returned, often in the afternoons, the old man walked majestically among the debtors, 
bowing to this one and to that one as a person of importance might acknowledge the greetings of inferior persons. Then it was that he beaned on his children, as he considered them, and received their rightful homage. Everything he did he tried to make consistent with his position.

One group of prisoners toward which the Father of the Iarshalsea conducted himself with particular condescension was the Collegians. They were the youngest prisoners who found a certain intimacy among themselves in the snuggery, a sort of lounge for the members and theirfriends. Here they boasted a comon fire, some tables and chairs, a boiler for hot water, and ale, if the money happened to be forthcoming. Every evening the Collegians gathered in the snuggery to drink, gamble, and otherwise entertain themselves until bed time. Dickens says of them, "It was evident from the general tone of the whole party, that they had come to regard insolvency as the normal state of mankind, and the payment of debts as a disease that occasionally broke out." As the Collegians never remained long at the prison, they received many visitors on Sundays. "There was a great deal of leave-taking going on in comers, as was usual on Sunday nights; and here and there in the dark, some poor woman, wife or mother, was weeping with a new collegian." 46 Mr. Dorrit looked upon these demonstrations of affection and sorrow as unnecessary, forgetful of the time he had bidien his wife goodbye in the gathering gloom of those very walls. He did not like to have the even tenor of his way disturbed, so wrapped up in the prison routine had his life become. 
As Amy had been born and reared inside the Marshalsea, it is not a wonder that at twenty-two we find her undersized, timid, quiet, and reserved. "with a still surviving attachment to the one miserable block of houses as her birthplace and home, she passed to and. fro in it shrinkingly now, with a womanly consciousness that she was pointed out to every one. Since she had begun to work beyond the walls, she had found it necessary to conceal where she lived, and to come and gois secretiy as she could, between the free city and the iron gates, outside of which she had never slept in her life.

Worldly wise in hard and poor necessities, she was innocent in all things else. Innocent, in the mist through which she saw her father, and the prison, and the turbid living river that flowed through it and flowed on." ${ }^{47}$

Always kind, always patient with the members of her family, all of whom proved difficult to manage, Iittle Dorrit Iived her uneventful life of sewing by the day and taking care of her father during the evening. Not once did a selfish thought cross her mind. Everything she did was for those thankless relatives of hers who took all and gave nothing in return. often she denied herself of her lunch that she might serve it to her father for his evening meal. All her earnings were spent for his comforts. As for her clothes, they were rusty black of poor quality, shiny from wear. Yet, withal, the Dorrit family accepted Amy's sacrifices without a feeling even of gratitude. As she had always cared for their wants from her childhood, so they still expected her to do so. It was as if they accepted her as an integral part of the prison and its pracices because she had been born there. But little Dorrit never saw any inconsist- 
ency in their treatment of her. She had never received any thanks for her services in their behalf, and consequently, - she expected none. Although her whole life had been spent behind the forbidding walls of the Narshalsea, and although she shrank from the life she saw all about her there; nevertheless, she remained untainted by its influences. That she never felt at ease out of its atmosphere, we can readily understand, even when her father was released. Yet only once do we find the influence of the prison on her life. That time was when her father was found to be the heir to a legacy and he was free to Ieave the prison.

"It seems so hard," said Iittle Dorrit, "that he should have lost so many years and suffered so much, and at last pay al1 the debts as we]1. It seems to me hard that he should pay In life and money both. Yes, I know I am wrong," she pleaded timidly, "don't think any worse of me; it has grown up with me here."

Nor can we blame her for her remorse. We wonder that the prison had not. Ieft a deeper scar than it did. Its most lasting mark was her sense of loneliness away from it. Always its shadow hovered near, taking away from her any pleasure she might have found in the beautiful things that surrounded her life after she left it. The curse of the varshalsea remained with her ali her life. Suffice it to say that as it had sheltered her father so many years, so it sheltered her lover some time later. As she had been born there, so she was married there in the prison parish. So it was that the old walls embraced her still, unrelentingly, the stain of their association lingering with her in the most solem hour of her life.

48. Text, p. 481. 
Thus Dickens gives us a picture of the debtor's prison throrigh the life of Iittle Dorrit, the child of the

- Marshalsea. It is a pathetic picture, to be true, with the prison tainting everything it touched, her mother, her father, her sister, her brother, and finally ever so lightly, her lover and husband. Nor did the author exaggerate conditions for the story's sake. His studies in penology at first hand had given him accurate infomation. Throughout his novels, he dealt with the Fleet, the Iarshalsea, the King's Bench, and Newgate Prisons, all of which he had visited and knew from first hand information. It is no wonder then that the novel, Iittle Dorrit, along with other progaganda that Dickens was able to produce was beneficial In the reformation of prison conditions throughout England. Trumble tells us, in his In Jail with Charles Dickens, that the Narshalsea was "officially abolished in 1849."

Thus again we see that Dickens through his novels was able to arouse some public sentiment against a radical social evil. Yet it was not just for the prisoners themselves that Dickens was so desirous of ridding the country of the debtors' prisons. He could hear the cry of the children of the prisoners' families who were doomed to a life of darkness and despair, a life tainted with the foulness of the prison which all time could not erase. At early ages in their existence, they felt the influence of ali that was degrading, and its influence remained to shadow their happiness and detract from their nomal joyfulness. The mark of the prison was graven in their lives. Always they would be pointed out as children of the prison, no matter how far removed their spheres might be from the life there. Even Iittle Domit felt the shadow of the Marshalsea 49. In Jail with Charles Dickens, Alfred Trumble, p. 106. 
drain from her cup of happiness something of its loveliness

- and leave it incomplete. Never was she free from its reach, regardiess of distance or of companions. Iife, for her, had received the blighting influence of the foul prison. Dickens had felt the influence of the prison in his own life and he could not bear for other children to feel it in theirs. In fact, such a hold did it have upon his life that for years after his father was released, he never passed it willingly. Nor did he mention its connection with his life until he had achieved a well-merited success with his novels. Then he mentioned it only to his friend and biographer, John Forster, when he gave him part of his autobiography. Only thon did John Forster realize that Dickens knew of the prison because he had spent some time there with his parents. That part of his life Dickens had hidden from the world, so deeply did he feel the shame of his having been at the larshalsea with his father who was a debtor. Yet, Dickens was to live to see some of the prison reforms that he hoped for realized. He was to know that he had some small part in causing public sentiment to demand better conditions for the prisoners and a better charice for their children to be protected from the taint of imprisonment during their incarceration. However, not until the end of the century were the reforms complete, and not until now are children finding the joyousness of living that the author was so desirous of procuring for them. 
CHAPTER IV. 


\section{Chapter IV.}

, PIP, THE CONVICT'S BEVETIC IARY.

Although Great Expe ctations, one of Dickens' last

novels, does not deal primarily with an abuse that affected little children directly; yet we feel that the author had in mind definitely the exposing of an abuse that indirectly caused children much hardship duming his lifetime, and even until our on $n$, in a modified way. That abuse was the hurding of convicts on condemed vessels and keeping them in irons during a long period of time. As a consequence of their Imprisoment, their children and families suffered many hardships and privations, even as do the families of all prisoners wherever they are incarcerated. In the particular instance dealt with in Great Expectations, the convict's little girl disappears as does his wife, and not until he is dying does he find out the fact that both his wife and child are living, although separated from each other. Not only were the convicts a hardship upon thoir families, but also they were the terror of the countryside near which they were imprisoned. The cry that one of them had escaped was a note of general alarm to all who heard it, as the country folk knew them to be desre rate and bent upon any mischief their fertile and perverted imaginations could conjure up. Thus, not only the families of the prisoners felt hunger, privation, and untold miseries due to the stigma of the punishment, but the country people near by believed themselves imposed upon by the drafting of their neighborhood into a harbor for criminals of the most degraded sor t. Consequently, we believe Dickens had the purpose in mind of relieving both peoples who were suffering because of the prisoners as well as relieving the prisoners themselves of the horrors of their im- 
prisoment as far as possible.

The novel centers around a little child, as do the other novels we have discussed. This novel, like David copperfield, is told in the first person so that it becomes, like that one, to some small extent autobiographical. We know that the author was a constant observer of the ships that found their way into the harbor at Portsmouth where his father was a clerk in the navy pey offlce. In his eanliest childhood, Dickens recalled seeing the great dark hulks lying at anchor In the dockyard, and he remembered his father's explaining that they were convict ships. Even then they seemed to him to have a lowering air, as if they were to be dreaded above everything that he knew.

In The Encyclopaedia. Britannica we find that convicts during Dickens time were disposed of in three ways, the road parties, the chain or iron gangs, and the penal settlements. The road parties were composed of the least desperate of the criminals. They were sentenced to hard labor, but were allowed a minimum of supervision, some freedom, and sufficient food of good quality. Travelling around the countryside wherever their work took them, these gangs felt their restraint the least of the three classes of convicts. Next in order of desperation were the iron or chain gangs. They too were sentenced to hard work which was constantly supervised with a military guara. From sundown till sunpise they were locked up in hulk, stockade, barrack, on caravan, and never were they relieved of the chains that they wore on their ankles. Order was enforced by the "scourger", a terrible whip that they all were in great dread. of. The most hrodened of the criminals were deported to Nor- 
folk Island, Noreton Bay, Port Arthur, or Tasman's Peninsula. That these colonies were the most disgusting places we can possibly imagine is quite true. In fact, the convicts themselves would rather have died on the gallows than have been sentenced to these cesspools of filth and vice. Such was the penal system of England until 1850 when sone bills of refrom began to find their way into Parliament; but even to our day, some of the greatest nations of the world have their penal settlements that are not much better than those existing during the first half of the nineteenth century.

As we have before mentioned, the novel centers around a Iittle child, Philip Pirrip, as orphan boy whom his sister has "brought up by hand". In his infancy, it was impossible for him to pronounce his whole name so that he shortened it to Pip, and Pip it remained. His had been a barren life, devoid of the love that becomes so natural to all children. only his sister's long-suffering husband had ever shown him any affection, and upon him Pip had lavished all the pentup love of his starved 1ife. At ten, he had become useful in a small way to Joe, his brother-in-law, in the forge, and also to his unrelenting sister, in odd jobs about the house. As his only companions had been, besides these two adults, the tomb stones marking the graves of his prrents and of his numerous sisters and brothers, the bleak and desolate marshes, and the few grown people who had visited his sister and her husband from time to time, he was a timid, lonely, reserved little boy, without the initiative that characterizes most children his age. He was always cuffed and scolded and beaten, with only Joe's kindness to lighten his 
otherwise sad existence.

As he was coming home late one aftemoon from his contemplation of the tombstones in the churchyard, he saw a hideous figure rise up out of the mist. "A fearful man, all in course grey, with a great iron on his leg. A man with no hat, and with broken shoes, and with an old rag tied around his head. A man who had been soaked in water, and smothered in mud, and lamed by stones, and cut by flints, and stung by nettles, and torn by briars; who limped, and shivered, and glared, and growled; and whose teeth chattered in his head as he seized me by the chin." He was one of the terrible chain or iron gang convicts, who had escaped, no one knows how, and who was in hiding in the marshes until he could manage to flee from the neighborhood. After scaring the child half to death, he made him promise to bring a file and some food and be there in the marshes at an early hour the next morning. With the threat, "You fail, or you go from my words in any proticular, no matter how small it is, and your heart and your liver shall be torn out, and roasted and ate", the child was allowed to depart, shaking in his shoes, both on account of the encounter with the convict, and also on account of the theft he had promised to commit. As he humpied home, he glanced back over his shoulder at the terrible apparition of the criminal and saw him "going on again towards the river, still hugging himself in both arms, and picking his way with his sore feet among the great stones dropped into the marshes here and there, for stepping-places when the rains were heavy, or the tide was in." 53

51. Great Expectations, Charles Dickens, from the Works of Charles Dickens, in thirty volumes, p. 2. This text will be used throughout this chapter. 
him drop down before my face and die of deraly cold. His eyes looked so awfully hungry, too, that when I handed him the file and he laid it down on the grass, it occurred to me he would have tried to eat it, if he had not seen my bundle........

He was gobbling mincemeat, meat bone, bread, cheese, and pork pie, all at once; staring distrustfully while he did so at the mist all around us, and often stopping-even stopping his jaws - to Iisten...."

A little later Pip informed the convict that he had met another escaped convict on the way down to the meeting place. After describing the man, he continued with the remark that there was the sound of connon firing the night before. Upon hearing that, the convict seemed a little surprised. Pip was surprised too, as he heard the firing at his house a mile away. "Why, see now!" said he(the convict). "When a man's alone on these flats, with a light head and a light stomach, perishing of cold and want, he hears nothin' all night, but guns firing, and volces calling. Hears? He sees the soldiers, with their red coats lighted up by the torches carried afore, closing in round him. Hears his number called, hears himself challenged, hears the rattle of the muskets, hears the orders 'Make ready! Present! Cover him steady, men!' and is laid hands on- and there's nothin'! Why, if I see one pursuing party last nightcoming up in order, Damn 'em, with their tramp, tramp- I see a hundred. And as to firing! Why, I see the mist shake with the cannon arter it was broad day. $-\ldots \ldots \ldots .{ }^{56}$ 
It is impossible for us to appreciate the horror of the convict's situation. A hunted man he became from the time he slipped away from the hulks, with everyone scheming to recapture him and return him to the misery he had just left. Just as Pip's convict saw the soldiers all that night and heard them firing their guns at him, so he was destined to hear them and see them for many years imprisonment. From the time he entered upon the life of the chain gang, he remained a marked man whom the law was obligated to punish as severely as the imaginations of man could humanely devise. That most of the convicts did not go insane is a. wonder, considering the hard work, the confinement, the evil companions, and, withal, the degradation of the sentence they were serving. That poor little Pip was frightened half out of his wits, we can well believe, as the convicts had always been pointed out to him as terrible beings.

That day being Christmas, Mrs. Joe had invited guests to partake of the yearly feast that she prepared to celebrate the occasion. They were all friends of Mr. and Mrs. Gargery, who took particular delight in embarrasing Pip by addressing morals to him at intervals during the conversation. As he was shivering from fright and suspense when his theft should be discovered, the pointed remarks affected him more than usual. Joe, meanwhile, consoled him with furtive offerings of gravy. As the time drew near for the liquors to be produced, his discomfiture increased. At length the fatal moment arrived when one of the guests gulped down a tumbleful of brandy and tar-water. (Pip had taken the convict most of the brandy and had filled the bottle with the horrid medicine that he hated.) Finaly, 
the constemation subsided, and he. was safe for another breathing spell. Then lrs. Joe went to get the piéce de résistance, a pork pie. $\Lambda$ s she discovered that it was missing, some soldiers knocked at the door, announcing that they were trailing two escaped convicts. Pip was saved; yet his conscience continued to trouble him for a long time.

That niaht, the soldiers were going out into the marshes to hunt for the escaped criminals; and Joe, Ir. Wopsle, one of the guests, and Pip went along. On the way, Joe whispered to Pip that he hoped they could not find the culprits, which wish Pip re-echoed in his own heart. If his convict were taken, he feared the worst of the threat the man had made. For some time they plowed through the soggy marshes, stepping from stone to stone, wading through water, and sinking down in the soft places, lighted only by the fitrul glare of the torches they carried. At length a shout made them change the direction of their going, and soon they carce in sight of the two convicts, who were fighting with a desperation that made force necessary to extricate them from each other.

"Water was splashing, and mud was flying, and oaths were being sworn, and blows were being struck, when some more men went dow into the ditch to help the sergeant, and dragged out separately, my convict and the other one. Both were bleeding and panting and execrating and struggling; but of course I knew them directly

The other convict was livid to look at, and in addition to the old bruised left side of his face, seemed to be bruised and torn all over. He could not so much as get his breath to speak, until they were both separately handcuffed, but leaned upon a soldier to keep himself from falling. 
'Lookee here!' said my convict to the sergeant. "Single-handed I got clear of the prison-ship; I made a dash and I done it. I could ha' got clear of these death-cold flats likewise- look at my leg; you won't find much iron on it- if. I hadn't made discovery that he was here. Let him go free? Iet him profit by the means as I found out? Iet him make a tool. of me afresh and alin? Once more? No, no, no. If I had died at the bottom there;' and he made an emphatic swing at the ditch with his manacled hands; 'I'd have held to him with grip, that you should have been safe to find him in my hold. " 57 No wonder he spoke so vehemently. The convict whom he had tried to murder had been the cause of his imprisonment years ago. He had been only an ignorant tool for his enemy to use then, but his chance for revenge had at last come.

Several. Years passed and Pip had not heard from his convict except once when an evil-looking stranger had given him two one-pound notes as a present from him. During the interim, the boy had had some real adventures, at least they were adventures to the country boy whose life was confined within narrow limits. He had been apprenticed to Joe as a blacksmith, an event that he had looked forward to for a long time. Yet when the event took place, he boy found himself dissatisfied. The reason was not far to find. He had been sent to play with a little orphan girl whose adopted mother had been deserted on the evening of her marriage. In consequence, wiss Havisham had reared her daughter. to hurt everyone with whom she came in contact. That the child's influence upon him was deadly, considering the life before him, 
Pip knew. She criticized him becaise he was not of nobility, because he wore coarse clothes, because he was a poor boy. As he in reality adoned the perverted child, pip came gradually to hate his home and all that it touched. Yet he was saved from total ingratitude by the amouncement that he had inherited great expectations which involved his going to Iondon to become a gentleman. His delight knew no bounds. In a week, he was off to the city, thrilled in every part of his being at the great opportunity that was his. Part of the stipulation connected with his good fortune was that he never ask the name of his benefactor, as that individual jeserved the right to make himself known at the proper time.

Suffice it to say that Pip became a gentleman, a thriftless, lazy individual, who spent far mone than his very liberal income and was always in debt, During the years, he had always attributed his good fortune to Miss Havisham, who was reputed to be very wealthy, and who had taken a fancy to Pip in the early days when he went to her house to play with Estella. He had never lost sight of her and her daughter and cxpected her to announce her kindness at any time.

Then one day the blow fell; for Pip's benefactor was revealed to him, and it was not Miss Havisham! It was Magwitch, the escaped convict wheom the child had befriended on the marshes one Christmas Eve many years before! In explanation, Nagwitch tells him:

"Yes, Pip, dear boy, I've made a gentieman of you! It's me wot has done it! I swore that time, sure as ever I earned a guinea, that guinea should go to you. I swore afterwards, sure as ever. I speculated and got rich, you should get rich. 
Lookee here, Pip, I'm your second father. You'remy son- more to me nor any son. I've put away money, only for you to.spend. When I was hired- out shepherd in a solitary hut, not seeing no faces but faces of sheep till. I half forgot wot men's and women's faces wos like, I see yours. I drops my knife many a time in that hut when I was eating my dimner or my supper, and. I says, 'Here's the boy again, a looking at me whiles I eats and drinks:" I see you many times as plain as ever I see you on them misty marshes. 'Lord strike me dead!' I says each timeand I goes out in the open air to say it under the heavens:but wot if I gets Iiberty and money, I'II make that boy a gentieman!" And I done it...."

The old man had kept one idea in his head all during his exile; for he had been sent to the penal settlement in west Australia from which very few of those who went ever returned alive. A little child's kindness was all that kept him from being his worst in that great, wild country, sparsely settled. at that time. The remembrance of a clild's innocent face had made him risk al I to see his boy again, regardiess of the consequence, death, if he were caught. Such goodness in the heart of a hardened criminal, whose whole life was one series of jail sentences touches us. We feel, as did Dickens, that the most degraded individual has a love in his heart for a little child, that he too feels the separation from his children and his ramily, and that he reserves a tender place in his memory for them even though he is far away among the dregs of humanity's wastes.

Magwitch's story touches our hearts, as he tells it to Pip and Herbert Pocket, Pip's dearest friend. 
"......... I've no more notion where I was born,

than you have- if so mch. I first became aware of myself, down in Essex, a thieving turnips for my living. Summun had run away from me- a man - a tinker-and he'd took the fire with him, and left me very cold.

"I know'd my name to be vigwitch, christen'd Abe. How did I know it? Wuch as I know'd the birds' names in the hedges to be chaffinch, sparrer, thmush. I might have thought it was all lies together, only as the birds' names come out true, I supposed mine did. So fur as I could find, there warn't a soul. that see young Abel lragwitch, with as little on him as in him, but wot caught fright of him, and either drove him off, or took him up. I was took up, took up, took up, to that extent that I reg'larly grow'd up took up.....

"This is a temible hardened one,' they says to the prison wisitors, picking out me. 'may be said to live in jails, this boy. "

Going from one crime to another, Magwitch had finally been arrested with compeyson, a swindler, forger, and thief. Compeyson placed all. the blame upon his employee, who was uncouth and uneducated, while he was a gentleman. The resilt was that Magwitch was sentenced to fourteen years while Compeyson was to serve only seven. The rest of his story, Dickens has already 59

told for us

We can scarcely imagine Pip's mental agony when he found out who was his unknown benefactor and heard his story. All the boy's hopes cmumbled in a heap anound him, and he was left helpless and utterly miserable. His childish horor of the convict remained, so that he could not sleep soundly for 
getting-up in the night to look at him. Every night was a period of nightmare and of terrible dreams. At length, the necessity for smuggling the convict out of the country dawned upon the boy as someone had found out about his return. Consequently, Pip and his two friends rowed Magwitch dow the river; but they were a day too late. The authorities had been notified to look out for him, and they apprehended him just on the verge of liberty. Once more he experienced a court trial, and once more he was sentenced, this time to death. However, he did not live to serve his sentence, as he passed away in the prison, with Pip at his side. Those last days were the happiest of his life, as life for him had always been bitter. Here, with Pip near him, and with the assurance of his Pip's future comforts in his heart, Magwitch knew what littie of. happiness had ever been his. Pip, too, found honest employment. Magwitch's fontune reverted to the state at his death, leaving Pip practically penniless.

Thus, we see another of the children of Dickens' novels, a little country boy, starved for the love of his deceased parents, who befriended a desperate criminal. We see too the horrors of the convict's existence in the terrible hulks and later in the penal settlement. It is through the life of the child that we are allowed to glimpse something of the untold miseries of those who were sentenced to life in one of the gangs and in the far-away colonial prisons that England made notorious. It was through the 1 ife of this 1 ittle child that the author hoped to expose the conditions existing in the afore-mentioned penal colonies and prison ships that some reform might result. Not many years later, the penal settlement in West Australia 
was closed, and some very definite refoms were passed by Parliament. We believe that Dickens' novel, Great Expectations, was instrumental to some extent in bringing about better conditions for England's convicts, as well as for their families and for the people in whose neighborhoods they were forced to labor. 
CHAPTER V. 
As we have before stated, we believe that Dickens helped to create public opinion that crystallized into defin-

- ite parliamentary action. It is noticeable that reforms were long in coming, partiy because the English people did not realize the situation of the numbers of poor wretches in the slums and pest-houses of their country, and partly because they were loathe to face the truth of the conditions presented to them by those who had made investigations. For example, Lord Ashley was ridiculed because of his unrelenting demands for better factory regulations, especially those that referred. to children. Parliament felt very self-righteous in view of the fact that it had passed a law prohibiting the labor of children under thirteen years of age in factories. Consequently, further legislation in that field was practically impossible for a time. Perhans the chief cause for poor regulations in all. fields of labor was the fact that not all of the English people were enfranchised. The poorer people had no chance for a voice In the government. Graft and bribery were rampant. Consequently, those people who were represented adequately suffered because their representatives were in many cases unscrupulous enough to ignore the needs of their constituencies when Parliament was in session. The result was a miscarrying of justice many times. That Dickens was cognizant of conditions that the representatives otherwise were willfully blind to, we can well believe. His travels to many parts of England brought him into contact with people of all walks of life; for Dickens was known for his love for and interest in people of every station. Especially was he 
interested in the children; for, he could never forget his own unfortunate childhood, and he could not bear to think of other little ones bearing the burden he bore, if it were in his power to help make their lives brighter and easier. That his efforts were not fruitless, we feel sure; for subsequent legislation bears witness to the efficacy of his labors. In the following pages we shall show some of the reform bills passed during Dickens' life and direatly following relative to the social evils he exposed thru the lives of the children we have discussed. That these laws were party the result of the author's novels, we believe to be true.

\section{Parish Reforms.}

oliver. Twist was written during the years 1837-1838, and published, like most of Dickens' novels, in monthly installments. The period covered by the novel is 1825-1837, dealing with the period of the greatest agitation caused by the new poor Law. That the law eventually proved a blessing to England's poor, we concede; yet we feel with the athor that its administration coupled with the extreme poverty of the people it affected proved it to be a blight instead of a blessing for many years after it was passed.

$$
\text { "The imregular development of the poor laws, from }
$$
the act of Elizabeth down to that of 1834, belongs to economic rather than to general history. It is enough to say here that in later years, and especially since the system of allowances adopted by the Berkshire magistrates at Speenhamland in 1795 had become general, the original policy of relieving only the destitute and helpless, and compeliting able-bodied men to earn their own living, had been entirely obscured by the intrusion of other ideas. The result was admirably described in the 
report of a commission appointed in. 1832, with the most comprehensive powers of investigation and recomendation. The comissioners were the Bishops of London (BIoomfield) and Chester (Sumner), Sturges Bourne, Edwin Chadwick, and four others Iess known, but well versed in the questions to be considered. A summary of the information collected by them, ranging over the whole field of poor-law management, was published in February, 1834. It astounded the benighted public of that day, and it sitil remains on record as a wonderful revelation of ruinous official infatuation on the largest possible scale. The evil system was found to be almost universal, but the worst examples of it were-furmished by the southem counties of England. There, an actual premium was set upon improvidence, if not on vice, by the wholesale practice of giving outdoor relief in aid of wages, and in proportion to the number of children in the family, legitimate or illegitimate. The excuse was that it was better to eke out scanty earnings by doles. than to break up households, and bring all their inmates into the workhouse. The inevitable effect of such an action was that wages fell as doles increased, that paupers so pensioned were preferred by the farmers to independent labourers because their labour was cheaper, and that independent labourems, fai ling to get work except at wages forced down to a minimum, were constantly falling into the ranks of pauperism

While the aggregate amount of the poor rate had risen to more than eight millions and a half, while same parishes were going out of cultivation and in others the rates exceeded the rental, there were cortain cases in the desert of agricultural distress where comparative prosperity still reigned. There were villages In which an enlightened squire or parson had set himself to 
strike at the root of pauperism, and had to initiate local reforms in the poor-law system. It was clearly found that, where out-door relief was abolished or rigorously limited, where no allowances were made in aid of wages, and where a manly self-reliance was encouraged instead of a servile mendicity, wages rose, honest industry revived, and the whole character of the village population was improved. Fortified by these successful experiments, the comissioners took a firm stand on the vital distinction, previously ignored, between poverty and pauperism. They did not shrink from recomending that, after a certain day, 'the workhouse test'should be enforced against all able-bodied applicants for relief,. They also advised a liberal change in the complicated and oppressive system of "parish settlement", whereby the free circulation of labour was constructed. They further proposed a very large reform in the administrative machinery of the poor laws, by the formation of parishes into unions, the concentration of workhouses, and above all, the creation of a central poor-law board, to consist of three comissioners, and to control the whole system about to be transfomed.

A bill framed on these lines, and remedying some minor abuses, was introduced by Altorp on April 17, having been foreshadowed in the speech from the throne, and carefully matured by the cabinet...... The bill was met with a very favourable reception, especially as its operation was limited to five years.......Vith some modifications of the bastardy clauses and other slighter amendments it was carried by a large majority, and received the royal assent on August $4 \cdot$ * 60.

60. Political History of England, Hunt and Poole, pp. 341-346. 
Thus the Poor Law of 1834 came into being. Its merits are obvious, and that it proved beneficial to Bngland no one can dispute. Yet, it had one flaw that its framers had not overlooked, but a flaw which.they were powerless almost to remedy. That weakness was the lack of provision for the needs of the poor from whom parish relief was withdrawn. Consequently, distress and dire need resulted for some years after the pasing of: the law. Added to the fact that support was withdrawn from many poverty-stricken people, was the disgraceful mismanagement of the parish unions. Iingard and Belloc state:

"The new Poor Law was now fully at work (1837) and its brutal tyranny was detested by the populace of town and country alike. Its iniquities were denounced by Oastler, a Tory Democrat, who, far more than Iord Shaftsbury, really prepared the way for the Factory Acts. They were described in not perishable language by the genius of young Dickens."

Trevelyan, in discussing the provisions of the new Poor Iaw, tells us that any poor person in need of relief could obtain it only at the cost of being imprisoned, segregated from his wife, deprived of all rights over his children, and generally treated as badly or worse than a convicted felon. It was a choice between starvation or slavery, worse than the conditions in the Colonies. The children were sold out, apprenticed, to any manufacturer who might be prepared to keep them alive for a few years for the advantage of their precocious labor. The people affected by the new law had had no voice in its passing. ConsequentIy, they had to endure its evils until they had the right to vote. That came partly in 1867, with the second Reform Bill, and partly in 1884, with the Third Reform Bill. 61. The Histoxy of England, Iingard and Belloc, Vol. XI, p. 535. 62. History of Englend, George liacaulay Trevelyen, pp. 521, 658, 686 . 


\section{Dickens himself said regarding the Poor Law:}

"But, that my view of the Poor Law may not be mistaken, I will state it. I believe there has been in Ingland, since the days of the Stuarts, no law so often infanously administered, no law so often openly violated no law habitually so ill-supervised. In the majority of the shameful cases of disease and death from destitution, that shock the Public and disgrace the country, the illegality is quite equal to the inhumanity - known language could say no more of their lawlessness." This statement was made as late as 1864. Thirty years after the Poor Law had been passed, the author was still agitating for refom in its administration. The value of the law he had never denied, if it were rightfully carried out. However, the lack of govemental supervision had continued to produce an unspeakable state of affairs which, if the Poor Law had been enforced as it should have been, would gradualiy have straightened out of itself. In oliver. Iwist, he had paved the way for the working out of the law advantageously by having the unscrupulous parish officers removed. Yet, he did not live to. see his ideal become a reality in the lives of the poor. His efforts in their behalf, nevertheless, eventually led to the reorganization of the paxish unions and the appointment of humane officers. Thus he had a definite part in paving the way for greatly improved conditions in the parishes of his beloved country.

\section{Educational Reforms.}

The educational system of Ingland sprang into being without form or plan. That the lords of the manors and their families were notoriously ignorant has long been conceded. 
Books were rare and expensive, and education, except of the most elementary sort, was not often found outside the church. After a time, the families in a district would hire a tutor to instruct their children and pay him jointly for his services. Thus private schools cane into being. As they were privately maintained, there was no question of supervision outside of the loris who were responsible for their upkep. Thus we have the explanation for the existence of such schools as Dickens exposed in Micholas Mickleby. As each sahool was a law unto itself, the subjects taught, the length of instruction, and the qualifications of the master arose only in each individual school. As a result, Ingland was dotted with schools of varying degrees of efficiency, yet with no consistency of standards. Such schools as Ir. Squeers' were possible; and that they did actually exist, the author himself states in no uncertain terms. It was such schools that the author was anxious to force out of the country.

Dealing with the period of 1830-1839, Micholas Mickleby was published like oliver. Twist serially in the same journal during the year 1839. It is noticeable that Dickens was dealing with conditions existing at the time of the novel. It is also noticeable that in 1839 a definite step forward was taken in educational refom. Prior to this time, a comission had been appointed to study the educational status of the country. As a result, a sum of twenty thousand pounds had been voted by Parliament, mainly to aid in the building of schools.

In 1839, "by means of an order in council (Parlia- 
ment) established a separate education office under the style of the Comititee- on Education, and the sum voted by Parliament was increased to thirty-nine thousand pounds". As the funds were limited, the comissioners were compelled to limit their efforts to assistance in school buildings. In distributing the money, they observed three restrictions:
(1) Right of inspection in all cases.
(2) Strict standards of structural efficiency.
(3) Building settled upon trusts pemanently securing
it to the education of poor children. 65

Thus educational reform was begun, but it was continued intermittently during the whole of the nineteenth century. As many of the schools were religious in character and support, Parliament in the folloving year gave the archbishops of the provinces power to pass upon the inspectors of their schools subsidized and taught by representatives of the Church of England. It also granted power to the Court of Chancery to substitute useful subjects for classical subjects entirely. In 1843, the comittee of Council voted to make grants for the training of teachers. Perhaps one of the most valuable reforms was instituted with the pupil-teacher system in 1846. The government voted to allow a small consideration to pupils who had attained to certain standards and who were able to teach the children in the grades below them. These pupil-teachers continued their training until they could qualify as regular teachers. Another bili in 1853 made elementary education possible to rural children by supplementing the grants of Parliament with capitation grants in the school areas. By 1856, the vice-president of the cornmittee of Council on Education became a minister responsible to Parliament. All this time the government grants for education 
had been growing until in 1858 they had reached 663,400 pounds. In the same yeas the duke of Jewcastle vas appointed chaiman of a commission to survey the school conditions and make a report with recommendations. The immediate result was the creation of county boards with power to levy a rate for the aid of existing voluntary schools. 66

It remained for the Education Act of 1870 to assure for the poor children of Ingland a common school education. McCarthy telis us that its tems were "to provide for public elementary education in Ingland and Wales. The basis of the measure was very simple, but also very comprehensive. Ir. Forster proposed to establish a system of school Boards in Fingland and Wales; and to give to each board the power to Irame by-laws compeling the attendance of all children, from five to twelve years of age, within the school district. The Government did not see their way to a system of direct and univeral compulsion. They therefore fell back on a compromise, by leaving the power to compel in the hands of the local authorities. Existing schools were in many instances, to be adopted by the bill, and to receive Govemment aid, on condition that they possessed a certain amount of efficiency in education, that they submitted themselves to the examination of an undenominational inspector, and that they admitted a conscience clause as part of their regulations. The funds were to be procured, partly by local rate, partly by grants from the Treasury, and partly by the fees paid in the paying schools. There were, of course, to be free schools provided, where the poverty of the population was such as, in the opinion of the local authorities, to render gratuitous instruction indispensable". 
in 1870 Dickens died, yet he lived to see education gradually assuming its proper place in the lives of his people. The hourible Yorkshire school was fast becoming a thing of the past, being. supplanted by a more humane and constructive institution of learning. Dickens' part in the refom movement was to produce evidence, as we have already indicated. It is notable thet the first really constructive measure dealing with education was passed during the publication of Nicholas Mickleby. It is also notable that Dickens continued to bring into his novels schools of varying types and degrees of efficiency. Practically all his novels deal with schools, most of them poor, but a few of them good, like Dr. Strong's school in David Coperfield. Never did Dickens give up his crusece for education for the poor until his death, when the great reform bill was passed making education possible for them. Mever did he fail to show the influence of poor training upon the Iife of the child. Always he pointed out the better way that finally came. His influence was shown more in the education act of 1839 than in the subsequent acts; yet we cannot fail to see his efforts behind the movenent for educational reform during the whole of his life-time.

\section{Prison Reforms.}

By the time Dickens wrote Iittle Dorrit, prison refoms were well on their way. Yet the author had started his crusade as far back as 1836 with Pickwick Papers when he exposed the evils of the Fleet Prison. In David Copperfield, he had dealt with the Kings Bench, and in Iittle Dorrit with the Marshalsea. In fact, in most of his novels, we find the prisons playing a prominent part. We know thet they held a peculiar fascination for him; yet, as he visited them, he was not blind 
to the terrible conditions in existence in all of them. He was constantly studying the vast throngs about him for character's in his novels, but he was also absorbing some of the horrors of the jail in order that he might help the poor wretches there to a better lot. Thus his crusade against the evils of the prisons began early, as did that against the evils of the educational system, and continued throughout his life. It culminated with Iittle Dorrit and the terrible larshalsea. In fact, so effective were his efforts that one of his letters to the Iimes regarding the hanging of Irr. and Irs. Mannings on Moverner 13, 1849, created such a flood of sentiment that eventually public hangings were abolished. These hangings were held in the jail yards where crowds gathered to witness the morbid spectacles. In the letter, Dickens said:

I was a witness to the execution of the lamings in Horsemonger Lane (the yard of Horsemonger Lane Gaol). I went there with the intention of observing the crowd gathered to behold it, and I had excelient opportunities until the spectacle was over........ When I came upon the scene, at midnight, the shrillness of the cries and howls that were raised from time to time, denoting that they came from a concourse of boys and girls already assembled in the best places, made my blood run cold........When the day dawned, thieves, low prostitutes, ruffians and vagabonds of every kind rlocked to the ground, with every variety of offensive and foul behavior. Fightings, faintings, whistlings, imitations of Punch, brutal jokes, turaltuous demonstrations of indecent delight when swooning women were dragged out of the crowd by the police with their dresses disordered, gave a new zest to the general entertainment. 
I an solemily convinced that nothing that ingenuity could devise to be done in this city, in the same compass of time, could work such ruin as oné public execution, and I stand astounded and appalled by the wickedness it exhibits. I do not believe that any community can prosper where such a scene of horror and demoralization as was enacted this morning outside Horsemonger Lane Gaol is presented at the very doors of the good citizens, and is passed by unlmown and forgotten."

Trumble, in his interesting account of the prisons of Dickens' day, gives us an interesting side-light upon the influence of the author's writings regarding the jails of the time.

"Dickens rarely wrote without a distinct object, and in 'Piclkick', desultory and irregular as the thread of the narrative is, he had such a purpose when he took the Fleet in hand. At the time he wrote of it (1836) the monstrosity was at its worst. The prevalent system of imprisoment for debt rendered the hideous gaol a tool at the hands of a vengeful enemy, and in those of a rapacious and dishonest man. The outrages to which it lent itself, at the call of swinding lawyers and comercial extortioners, had comenced to attract public attention. That the chapters on the Fleet in 'Piclwick' bore a share in arousing the general indignation cannot be questioned. They shaped the popular sentiment and gave it a war-cry. But the good work was not to be done in a day. It required an Act of Parlianent debated on and contested with the usual ppnderous procrastinativeness, to rid the earth of the Fleet. The Act was at last passed in 1842, and by it the prison was abolished, and its inmes were drafted into the Queen's Prison. The Pleet was later sold to the corporation of the City of Iondon, and in the spring of 1846 it was razed to the ground. This site to-day is marked by business buildings, whose ceaseless industry makes a strange monument for the stagnant and idle life of which the spot was once the scene." 70

By 1840, a model prison, Pentonville, had been constructed and within six years fifty-four others had been built on/the same plan. In fact, it proved to be a model for the world to follow.

69. In Jail with Charles Dickens, 71. $\frac{\text { In Jail with Charles Dickens, }}{\text { The Incyclopaedia Britannica, }}$ Alfred Trumble, pp. 108-110. Alfred Trumble, pp. 104, 105. Vol. XXII, p. 363. 
Yet imprisonment for debt had not yet gone out of existence by 1855, the year he published Iittle Dorritt, and Dickens was detemined to effect some reform for the debtors of his country. His father's terrible experiences were still haunting his memory, and he felt that he must better conditions for others who were, like him, imprisoned for debt. Iittle Dorrit was a distinct effort toward that goal. In 1831 and again in 1842, attempts had been made to settle the question, but several other measures were necessary before the laws concerning debtors were at all humane or workable. In order to make the final law enacted during Dickens' life clear, we shall go back to that of 1849 and trace the others from it. "Under the act of 1849, a totally new principle was introduced by the provision that a deed of arrangement executed by six-sevenths in number and value of the creditors for ten pounds and upwards should be binding upon all the creditors without any proceedings in or supervision by the court." The wealness of this law proved to be that the debtor detemined himself who were and who were not his creditors, "without any opportunity for testing the claims of those who signed the deed to control the administration of the estate". Thus, "fraudulent arrangements" and "laxity in administration of the debtor"s estates" ensued. "......The Act of 1849 was, however, to some extent modified by subsequent decisions of the courts that to make a composition arrangement binding it must be accomplished by a complete cessio bonorum; but this qualification was removed by the act of 1861 which made such arrangements binding without a cessio and reduced the majority required to make a deed or arrangement binding on all creditors, to a majority in number and 
pounds and upwards. 'The result was an enomous increase in frovdulent arrangements." In fact Sir Robert Collier, the attorney-general, stated that the laws of 1849 and 1861 enabled a bankrupt to "defraud those to whom he was indebted and to set them at defiance".

The result was a new act in 1869 providing for meetings of the creditors whose claims were, for voting purposes, presided over and adjuoicated on by the registrar of the court; the bankrupt had to pass a public examination in court, which, although chiefly left to the trustee appointed by the creditors, afforded some opportunity for investigation; and the bankrupt could not obtain his discherge without the approval of the court and in certain circumstances the consent of the creditors. An independent official, the comptroller in bankruptcy, was appointed to examine the accounts of the trustees and refer the demeanors to the court. In another place we read, "Imprisomment for debt, the evils of which have been so graphically described by Dickens, was abolished in England by the Debtors Act of 1869, except in cases of default of payment of penalties, default by trustees, and certain other cases"

It was Dickens' novel, Iittle Dorrit, that had a decided influence in the legislation abolishing the practice of imprisonment for debt. Although the period covered by the novel is 1827-1830, yet we feel that the author was dealing with the question in 1855, the year of its publication. As we quoted in Chapter III, Mr. Dorrit attended meetings of his creditors with "sharlis" versed in the "wiles of benkruptcy" 
in order to straighten out his affairs. These meetings were provided for by the law of 1849 , as we mentioned above. Due to the faultiness of the law, Mr. Dorrit was forced to spend twentyfive years at the Narshalsea because of inability to arrange his business with his creditors setisfactorily. It was just fourteen years later that Dickens saw his hopes realized by the abolishment of imprisoment for debt except in some specialized cases. His vivid descriptions of its evils had had their part. in bringing about a chance for the debtors of his country to win back their self-respect and escape the horrors of the prisons both for themselves and also for their families.

\section{Refoms Regarding Penal Servitude.}

As Dickens had his part in abolishing the practice of imprisoment for debt, so he aided in the revision of the penal. code of his country. As he had feared the prison hulks as a child, so he continued to feel their sinister influence as a man. As late as 1850, no definite legislation had been passed in regard to bettement of the conditions affecting the convicts in servitude in England and her colonies. Finally in 1853 Parliament passed the Penal. Servitude Act which substituted shorter terms of penal servitude for those convicts who had been transported, if their behavior merited Ieniency. However, the measure only stated what had been the practice for years. After the term was over, the convicts relapsed into their former bad conduet.

Dickens' novel, Great Expectations, published in 1860, deals with the period of 1830-1860. Thus the question of penal servitude was brought to the attention of the people at a crucial time. New prisons were still in the process of construction; 
legislation in many fields was being passed; and governmental reforms wère in the minds of the people. Consequently, the time was ripe for the remedying of another evil that Dickens was chxious to have dealt with. Three years after the publication of Great Ixpectations, in 1863, a comittee of inquiry was appointed by the House of Comons to inquire into conditions regarding penal servitude and to make a report with recomendations. The result was the "Mark" system. By it, marks were. given the convicts for good conduct. When they had earned so many marks, they were allowed a certain freedom by being sent to a colony to finish our their tems with a minimum of supervision. Thus, only three years were required for Dickens to realize definite action because of his novel. Four years later, the penal colony in West Australia, where Iagwitch spent so many years, was closed. Nevertheless it was not until 187r1878 that any definite action was taken to better conditions within the penal prisons themselves. At that time the practice of segregating criminals was instituted. Finally in 1880, the criminals sent to prison for the first time were separated from those who were habitual offenders against the law so that the new convicts might be protected from the association of desperate men.

Thus, we see that Dickens had a definite part in the abolishing of some evil practices connected with penal servituce by means of another of his novels, Great Expectations, just as we have seen his influence in the abolishing of other hamful practices affecting Ingland's poor. Although he lived only long enough to see the beginning of the penal reforms, yet he had the satisfaction of knowing that others would follow until the lot of the convicts was greatly improved. 
.

CONCLUSIOIN. 


\section{CONGTUSION.}

There are some valuable conclusions to be drawn from the foregoing pages. In the first place, Dickens had a definite purpose in dealing with children, principally in the slums of his beloved Iondon. However, he did not confine himself to the children, as he dealt with social questions affecting all the poor as well as those concerning their children alone. In the novels we have cited, he was exposing social evils through the medium of the lives of the children, as much because he loved them, as because he felt that the appeal of their innocence would achieve ends that he could not otherwise achieve. Then, too, there was that larger return, the desire on his part to make their lives happier and easier by relieving them of unnecessary hardships and toil. In consequence, he took upon himself the task of exposing to his readers the evils affecting the poor, through the medium of his novels. It was not his purpose to semonize. Nor did he moralize pointedy at any time. The facts of his novels did both, as he intended that they should: yet their teaching was accepted unconsciously by his followers. The sufferings and hardships of the poor. whose Iives he depicted produced a sympathy that expressed itself in definite action. Constructive action was the end he had in view.

In the second place, we believe that Dickens achieved the purpose that he set for himself. By 1870, the jear of his death, reforms in many fields were coming into being. Parish mismanagement was soon to be corrected, even though gradually. Education had been made available to scores of children who had fomerly been denied the privilege. The old prisons had been 
razed to the ground to make way for the new. Imprisonment for debt, except in a few specialized cäses, had been abolished. Penal settlements were being closed, and the lot of the convicts improved. In fact, in all these refoms we have seen the genius of the author as the public opinion aroused by his novels has achieved, in part, some definite refoms. That he failed to deal with child labor in the mines and the factories is easy to explain. Iord Shaftsbury's efforts in the field of the factories produced the Factory Acts, culminating in the "Factory and Workshop Consolidation Act" of 1878. 75 others were dealing with the question of the mines, so that Dickens felt his aid unnecessary. (Nevertheless he did deal with adult labor in the factories in his novel, Hard Times, but he did not even touch the question of child labor there.)

A third conclusion to be drawn. from the preceding discussion is the fact that Dickens painted for us a remarkable picture of his time. Understanding the sufferings of the poor as he did, he was able to depict them in their true light. If he painted evil in the darkest of colors, it was only that wrong might appear the more hideous in contrast to right, which always, in his novels, triumphed. Never did he compromise with wrong. Mever did he fail to express what he believed, even regarding the laws of his country that he felt were unjust, if by so doing he could wield an influence for good. Only Death itself caused him to close his crusade against the evils of his day. The picture that he gave us is nade up of lights and shadows, yet with the shadows predominating. Seeing his day in 
a perspective not given to many men, he is equalled in his portreyal of the lives of society. .

Let us think then with reverence of Dickens, one of the greatest of English authors, who burned out his life in his efforts in behalf of the poor of England. 


\section{$\therefore$}

BIBIIOGRA PHY. 


\section{BIBITOGRAPHY}

Iife, Ietters, and Speeches of Charles Dickens, in two volumes, New York, 1894 .

Iife of Charles Dickens, Frand T. Marzials, Philadelphia, undated.

Dickens, Adolphus William Ward, New York, from English Men of Ietters, edited by John Morley.

Charles. Dickens and his Friends, W. Teignmouth Shore, London, 1909.

In Diclrens's Iondon, F. Hoplrinson Smith, New York, 1914. Charles Dickens, A Biography from New Sources, New York, 1928. Dickens a.s an Eidtor, James I. Hughes, New York, 1914. O1d Friends, William Winter, New York, 1909. Charles Dickens, a Critical Study, George Gissing, New York, 1904. The Charles Dickens Originals, Bdwin Pugh, New York, 1912. Iife of Dickens, John Forster, Abridged and Revised by George Gissing, Iondon, 1907 .

Appreciations and Criticisms of the Works of Charles Dickens,

G. K. Chesterton, London and IFew York, 1911.

My Father as I RecaII Him, liry Dickens, New York, 1900. In Jail with Charles Dickens, Alfred Trumble, New York, 1896. The History of Bngland, in eleven volumes, John Iingard and Hilaire BeIloc, Volume XI, New York, 1915.

Facational. Reform, Fabian Ware, London, 1900. Chailes Dickens, His Iife, Writings, and Personality, Frederic G. Kitton, Iondon and Edinburgh, 1906 . Charles Dickens and Other Victorians, Sir Arthur QuilierCouch, New York and London, 1915. 
The Iife of Chaqles Dicicens, John Forster, in two volumes, Mew York, 1902 .

The Days of Dickens, Arthur I. Hayward, New York, 1926. A Fundred Wonderful Years; Social and Domestic Iife of a Century, 1820-1920, Mrs. C. S. Peel, ITew York, 1927. The Fngland of Dickens, Walter Dexter, Philadelphia, undated. Charles Dickens and his Girl Heroines, Belle Loses, New York and Iondon, 1911.

The Political History of England, in twelve volumes, edited by William Hunt and Reginald Poole, London, 1919, Volume XI, $1801-1837$.

Cherles Dickens, A Sketch of his Life and Works, F. B. Perkins, 1870 .

A History of our own Iimes, Justin NoCarthy, in two volumes, New York, 1880 .

History of Bngland, George Iacauley Trevelyan, Iondon, 1926. English Iocal Govermment: Statutory Authorities for Special

Purposes, Sidney and Beatrice Webb, London, 1922. An Introduction to the Industrial and Social History of England, Edward P. Cheyney, London, 1906. The Works of Charles Dickens, in thirty volunes, Hew York, undated.

The Iife and Adventures of Micholas Mickleby, Charles Dickens, in two volumes, London, undated. The Bncyclopaedia Britanica, Bleventh Edition, 1910-1911, New York, 19I1, Vols. XXII, VIII, VII, III. 